NBER WORKING PAPER SERIES

THE LABOR MARKET CONSEQUENCES OF REFUGEE SUPPLY SHOCKS

\author{
George J. Borjas \\ Joan Monras \\ Working Paper 22656 \\ http://www.nber.org/papers/w22656 \\ NATIONAL BUREAU OF ECONOMIC RESEARCH \\ 1050 Massachusetts Avenue \\ Cambridge, MA 02138 \\ September 2016
}

Borjas: Professor of Economics and Social Policy, Harvard Kennedy School; Research Associate, National Bureau of Economic Research; and Program Director, Program on Labor Mobility, IZA. Monras: Assistant Professor of Economics, CEMFI; and Research Affiliate, IZA. We are grateful to Andrea Ichino, Joan Llull, Jan Stuhler, and four referees for valuable comments on a previous draft of this paper. The paper was prepared for presentation at the 64th Panel Meeting of Economic Policy in October 2016 in Florence, Italy. The views expressed herein are those of the authors and do not necessarily reflect the views of the National Bureau of Economic Research.

NBER working papers are circulated for discussion and comment purposes. They have not been peer-reviewed or been subject to the review by the NBER Board of Directors that accompanies official NBER publications.

(C) 2016 by George J. Borjas and Joan Monras. All rights reserved. Short sections of text, not to exceed two paragraphs, may be quoted without explicit permission provided that full credit, including (C) notice, is given to the source. 
The Labor Market Consequences of Refugee Supply Shocks

George J. Borjas and Joan Monras

NBER Working Paper No. 22656

September 2016

JEL No. J23,J6

\begin{abstract}
$\underline{\text { ABSTRACT }}$
The continuing inflow of hundreds of thousands of refugees into many European countries has ignited much political controversy and raised questions that require a fuller understanding of the determinants and consequences of refugee supply shocks. This paper revisits four historical refugee shocks to document their labor market impact. Specifically, we examine: The influx of Marielitos into Miami in 1980; the influx of French repatriates and Algerian nationals into France at the end of the Algerian Independence War in 1962; the influx of Jewish émigrés into Israel after the collapse of the Soviet Union in the early 1990s; and the exodus of refugees from the former Yugoslavia during the long series of Balkan wars between 1991 and 2001. We use a common empirical approach, derived from factor demand theory, and publicly available data to measure the impact of these shocks. Despite the differences in the political forces that motivated the various flows, and in economic conditions across receiving countries, the evidence reveals a common thread that confirms key insights of the canonical model of a competitive labor market: Exogenous supply shocks adversely affect the labor market opportunities of competing natives in the receiving countries, and often have a favorable impact on complementary workers. In short, refugee flows can have large distributional consequences.
\end{abstract}

\author{
George J. Borjas \\ Harvard Kennedy School \\ 79 JFK Street \\ Cambridge, MA 02138 \\ and NBER \\ gborjas@harvard.edu \\ Joan Monras \\ CEMFI \\ Calle Casado del Alisal, 5 \\ 28014 Madrid \\ jm3364@gmail.com
}




\title{
The Labor Market Consequences of Refugee Supply Shocks
}

\author{
George J. Borjas and Joan Monras*
}

\section{Introduction}

The recent inflow of hundreds of thousands of Syrian refugees into many European countries has inevitably rekindled interest in documenting the determinants and consequences of such "refugee supply shocks." Although the war in Syria started in 2011, and refugee camps formed in the area soon thereafter, the refugees initially moved mainly to Lebanon, Jordan, and Turkey. As the Syrian conflict continued and escalated, however, the refugees began to move to Europe through Greece, with alternate routes quickly emerging in Hungary, Austria, and the Balkans. It is difficult to enumerate precisely just how many refugees have already entered the continent, but many news reports claim that over 1 million asylum seekers arrived in Europe in calendar year 2015.

This inflow of refugees has already generated a great deal of political conflict in all the receiving countries, and has exposed major fissures in the economic, social, and cultural fabric that holds together the European Union. Much of the controversy surrounds the long-term implications of the open-door policy implicit in German Prime Minister's Angela Merkel's unilateral assertion that "the fundamental right to asylum for the politically persecuted knows no upper limit" (Alexe, 2015).

The full consequences of the epochal events now reverberating throughout Europe will not be known for many years (or perhaps even decades). Nevertheless, the persistent influx of large numbers of refugees raises fundamental questions about their impact that encourage a "revisiting" of other refugee supply shocks in other countries and at other times to determine if there are universal lessons to be learned from such shocks.

This paper provides such a revisiting. Despite the obvious differences in the factors that have motivated refugee shocks throughout history-including the size and timing of

\footnotetext{
* Borjas: Professor of Economics and Social Policy, Harvard Kennedy School; Research Associate, National Bureau of Economic Research; and Program Director, Program on Labor Mobility, IZA. Monras: Assistant Professor of Economics, CEMFI; and Research Affiliate, IZA. We are grateful to Andrea Ichino, Joan Llull, Jan Stuhler, and four referees for valuable comments on a previous draft of this paper. The paper was prepared for presentation at the 64th Panel Meeting of Economic Policy in October 2016 in Florence, Italy.
} 
the flows, the human capital of the refugees, and the countries and localities affected by the upheaval - there are important similarities as well, and these similarities can help provide a unifying framework for how to think about the labor market consequences of current or future supply shocks.

Almost by definition, refugee supply shocks are exogenous along a number of important dimensions. The timing of the supply shock typically has little to do with economic conditions in the receiving countries. The size of the supply shock depends at least partly on the circumstances that created the exogenous political turmoil. And the skill composition of the refugees often hinge on the nature of the political conflict that motivated the exodus. In some cases, these political events lead to an outflow of high-skill workers, while in other cases they lead to an outflow of low-skill workers.

The paper reexamines the evidence surrounding some key historical refugee supply shocks. In particular, we document the labor market consequences of four distinct shocks, each of which has been analyzed separately in previous research:

(1) The flow of Cuban refugees in the Mariel boatlift in 1980, a supply shock that affected mainly the city of Miami (Card, 1990; Borjas, 2016, 2017; Peri and Yasenov, 2015).

(2) The flow of refugees into France, both French repatriates and Algerian nationals, that followed the conclusion of the Algerian War of Independence in 1962 (Hunt, 1991).

(3) The flow of Jewish émigrés to Israel following the collapse of the Soviet Union in the early 1990s (Friedberg, 2001).

(4) The flow of refugees into several European countries from the long Yugoslav Wars during the 1990s (Angrist and Kugler, 2003).

Table 1 summarizes some of the essential details that characterize these supply shocks. There are obviously large differences in the number of refugees involved. The Mariel supply shock, for example, involved a total of about 120,000 refugees; the exodus created by the Yugoslav Wars involved 250,000 persons; the shock of Soviet émigrés into Israel involved almost 500,000 refugees; and nearly 1.5 million refugees entered France after the end of the Algerian conflict. The different shocks also differed substantially in the skill composition of the refugee population. The Mariel shock, for instance, consisted mainly of very low-skill workers, with most of them lacking a high school education; the Soviet émigrés entering Israel were disproportionately high-skill, with most of them having 
at least a college degree; and the refugee flow exiting Algeria consisted of both extremes, with many low-skill Algerian nationals and many at least moderately skilled French repatriates.

Although each of these shocks has been examined independently in prior research, our analysis differs in three crucial ways. The existing studies "pick and choose" a particular methodological approach, often based on the type of data available or on the idiosyncratic characteristics of a particular shock, to document their impact. An obvious problem with this piecemeal approach is that it is unclear if the empirical findings truly reveal universal insights about the impact of refugee supply shocks, or instead reflect the fact that a particular researcher chose a particular methodological approach to study the impact of a particular episode. Put bluntly, are the findings documented in the literature sensitive to the choice of methodological approach used to examine the impact of a particular supply shock?

Our analysis instead derives a single empirical approach based on the implications of factor demand theory. In principle, this methodological approach can be applied to measure the consequences of any refugee supply shock. The theoretical derivation indicates exactly the type of correlation between labor market outcomes and the number of refugees that should be estimated in any specific context. And it also delineates precisely the conditions under which that observed correlation can be interpreted as measuring a causal impact of the refugee-induced increase in the supply of labor.

Second, our analysis plays close attention to isolating the particular groups that are most likely to be affected by refugee supply shocks. As noted earlier, the supply shocks sometimes consist of high-skill workers, while in other cases they consist of low-skill workers. One important lesson from our examination of the evidence is that the adverse labor market impact of refugee supply shocks can only be properly estimated when the analysis closely matches the skills of the refugees with those of the native workers who are most likely competing in the same labor market.

Equally important, the emphasis on the skill distributions of native and of refugees implies that we can also examine the impact of the supply shocks on potentially complementary native groups. For example, the low-skill Marielitos may have had a beneficial impact on the wage of high-skill Miamians, while the high-skill Soviet émigrés 
may have had a beneficial impact on low-skill Israelis. These potential complementarities are obviously an important component of any complete assessment of the labor market consequences of refugee supply shocks. Our analysis of the natural experiments generated by the various supply shocks provides the first estimates of the cross-effects of immigration that are based entirely on observed data and are not contaminated by any extraneous assumptions about the functional form of the aggregate production technology.

Finally, rather than rely on proprietary or confidential data, we use the publicly available censuses maintained at IPUMS. Although these data are sometimes less than ideal, they can be easily adapted to measure the labor market consequences of refugee supply shocks on both competing and complementary workers. In view of the very contentious policy debate over the economic impact of immigration, the use of publicly available data has one non-trivial implication: Our results are fully reproducible.

The empirical analysis reported below uses the theory-derived empirical specification to estimate the impact of the Marielitos, of the French repatriates and Algerian nationals moving to France, of the flow of Soviet émigrés into Israel, and of the refugees from the Yugoslav wars into several European countries. Despite the obvious differences in the historical events that we examine, in the skill composition of the refugees, and in the countries and localities affected by the shocks, the use of a unified empirical framework to study each of the episodes reveals a common thread: Exogenous refugee supply shocks have an adverse effect on the labor market opportunities of competing natives in the destination countries. Depending on the episode and the data, we document that the shock sometimes reduces the wage of competing workers; sometimes it reduces their employment rates; and sometimes it reduces both. At the same time, however, the empirical analysis also reveals that exogenous supply shocks often have a beneficial impact on the employment opportunities of complementary native workers. In short, refugee supply shocks have sizable distributional consequences in the labor markets of receiving countries. 


\section{Framework}

It is instructive to begin the discussion by considering how one would go about estimating the labor market impact of immigration if one had an ideal empirical setting and ideal data. In particular, suppose that the receiving country has a competitive labor market and that volatile political conditions abroad randomly generate a flow of refugees. It is crucial to emphasize that the refugee supply shock is random along all relevant dimensions, including the timing, the size and skill composition of the flow, and the eventual geographic sorting of the refugees in the receiving country.

The economy of the receiving country is composed of $r$ isolated labor markets. These labor markets can be defined along a number of characteristics commonly shared by groups of workers. To fix ideas, and because this is the context most often seen in the existing literature, it is useful to think of the index $r$ as indicating a regional labor market (although our discussion can be easily applied to alternative classifications, such as an occupation). In this ideal setting, workers cannot move from one labor market $r$ to another in response to either supply or demand shocks. The production technology in the firms populating each of these markets uses $s$ different types of workers that are defined along another characteristic, such as their educational attainment. Pairs $(r, s)$ of labor markets and factor types define each of the $k$ different "cells" in which the national labor market can be subdivided and for which data are available.

We can derive a standard isoelastic labor demand function for each of these $k$ cells by assuming that competitive firms maximize profits in each market. Prior to the refugee supply shock $(t=0)$, there are $L_{r s 0}$ workers in region $r$ of skill type $s$. The pre-shock CES aggregate production function for region $r$ is given by:

$$
Q_{r 0}=\left[\sum_{s} \alpha_{s 0} L_{r s 0}^{\delta}\right]^{1 / \delta}
$$

where $\delta=(\sigma-1) / \sigma$; and $\sigma$ is the elasticity of substitution across worker types. Note that the weights attached to the various skill groups (i.e., the $\alpha$ 's) can vary over time, due perhaps to technological shifts that may favor one skill group over another. 
Profit maximization implies that we can write the wage paid to workers in cell $(r, s)$ at $t=0$ as:

$$
\log w_{r s 0}=\log p_{r 0}+\log \alpha_{s 0}+\eta \log Q_{r 0}-\eta \log L_{r s 0}
$$

where $p_{r 0}$ is the price level in region $r$ prior to the supply shock, and $\eta(=1 / \sigma)$ is the wage elasticity.

It is useful to think of the variable $L_{r s 0}$ as giving the number of pre-existing workers in cell $(r, s)$ prior to the supply shock. For simplicity, we will often refer to this pre-existing workforce as "natives," but it should be obvious that $L_{r s 0}$ could potentially include both native- and foreign-born workers. In the short run, with the quantity of other factors of production held constant, economic theory predicts that an increase in the size of the workforce in a particular region-skill cell reduces the "own" wage. ${ }^{1}$ Note also that $w_{r s 0}$, the equilibrium wage prior to the refugee supply shock, incorporates the impact of all immigration-induced supply shocks prior to the random political upheaval that generates the new flow of refugees.

The labor markets in the receiving country are then "shocked" by the political upheaval abroad. This upheaval sends an influx of $M_{r s}$ new refugees into each region-skill cell. We can write the post-shock marginal productivity condition as:

$$
\log w_{r s 1}=\log p_{r 1}+\log \alpha_{s 1}+\eta \log Q_{r 1}-\eta \log \left(L_{r s 1}+M_{r s}\right)
$$

The wage change observed in cell $(r, s)$ as a result of the refugee supply shock can then be written as:

\footnotetext{
${ }^{1}$ Differentiating equation (2) with respect to $L_{r s 0}$ yields $\partial \log w_{r s 0} / \partial \log L_{r s 0}=-\left(1-\kappa_{s}\right) / \sigma$, where $\kappa_{S}$ is the share of income accruing to skill group $s$.
} 


$$
\begin{aligned}
\Delta \log w_{r s} & =\Delta \log p_{r}+\eta \Delta \log Q_{r}+\Delta \log \alpha_{s}-\eta \log \frac{L_{r s 1}+M_{r s}}{L_{r s 0}}, \\
& =\theta_{r}+\theta_{s}-\eta \log \frac{L_{r s 1}\left(1+m_{r s}\right)}{L_{r s 0}}, \\
& =\theta_{r}+\theta_{s}-\eta \log \frac{L_{r s 1}}{L_{r s 0}}-\eta m_{r s},
\end{aligned}
$$

where $\theta_{r}=\Delta \log p_{r}+\Delta \log Q_{r}$, and is captured by a region-specific fixed effect; $\theta_{s}=\Delta \log \alpha_{s}$ and is captured by a skill-specific fixed effect; and $m_{r s}=M_{r s} / L_{r s 1} \cdot{ }^{2}$ Note that $m_{r s}$ gives the relative size of the supply shock: the percent increase in the number of workers due to the entry of refugees into cell $(r, s)$.

In addition to the fixed effects $\theta_{r}$ and $\theta_{s^{\prime}}$ equation (4) has two regressors. Not surprisingly, the wage change depends on the refugee supply shock. Although there is much confusion in how this supply shock should be measured (compare, for example, Borjas, 2003; and Card and Peri, 2016), the marginal productivity condition that is the foundation of the theory-based empirical approach clearly indicates that the measure of the supply shock should give the percent by which immigrants increased the size of the workforce, with the base being the number of native workers in the post-shock period. ${ }^{3}$

Equation (4) also shows that the wage in cell $(r, s)$ may have changed because the number of native workers in that labor market might have risen or fallen between the two periods. Some of the change in the number of natives may be due to demographic factors that are unrelated to changes in economic conditions during the relevant period, such as mortality in the pre-existing workforce, the labor market entry of workers born many years earlier, or secular trends in the skill mix of the native population. But some of the change in $L_{r s}$ may be endogenous, induced by the refugee supply shock itself. In other

2 The derivation of equation (4) uses the approximation $\log \left(1+m_{r S}\right) \approx m_{r S}$, which is appropriate as long as the refugee supply shock is "small."

${ }^{3}$ Card and Peri (2016) argue that it is preferable to use the pre-shock period workforce as base (see also Dustmann et al., 2016). The bias induced by any particular specification is related to the endogenous labor supply response of the natives. We discuss the labor supply response in greater detail below. 
words, the entry of the $M_{\mathrm{rs}}$ refugees might generate a labor supply response in the native population.

As a starting point, suppose that the change in the supply of pre-existing workers is exogenous, due to long-term demographic factors. We have already assumed that the refugee supply shock is, by definition, exogenous. The correct specification of a regression model that estimates the impact of the refugee supply shock would then relate the wage change in a particular labor market to the percent change in supply in the native population and to the percent change in supply attributable to the refugees (as well as region and skill fixed effects). The two "supply" regressors should have identical coefficients, and those coefficients, as indicated by equation (4), should equal the wage elasticity $\eta$.

\section{Statistical Difficulties}

It is obvious that the real-world data typically available to measure how immigration affects labor markets do not meet the ideal conditions of the refugee supply shock discussed above. Although the timing of the shock may be independent from economic conditions in the receiving country, the actual number of refugees as well as their distribution across the $(r, s)$ cells will be affected by those conditions. After all, only those persons who have the most to gain by leaving will be the ones likely to end up as refugees. Moreover, those self-selected refugees will tend to settle in those regions of the receiving country that offer the most favorable economic opportunities.

Natives will also respond to the refugee supply shock. These responses imply that the region-skill cells cannot be thought of as isolated islands, and that supply shocks that affect one cell have spillover effects on other cells. In the short run, for example, native workers or firms might move from one regional labor market to another to take advantage of the changes in the wage structure. In the long run, the demographic variables that may be the "fundamentals" determining endowments of each factor of production are no longer exogenous, as natives might pursue particular types of human capital investments and avoid others. 
In addition to these endogeneity issues, there is a measurement problem inherent in this type of analysis that might generate substantial bias: The skills that refugees acquired prior to the political upheaval might not be very valuable to employers in the receiving country. In other words, some of those skills may evaporate during the move. For instance, a college degree acquired abroad might not have the same "knowledge content" as a college degree acquired in the receiving country. Similarly, language difficulties might impose a barrier for migrants wishing to enter certain occupations. As a result, the observable skills of the refugees, as measured by years of educational attainment or professional certificates, provide erroneous information about which specific factors of production they are truly competing with or complementing. This measurement error in the size of the supply shock in cell $(r, s)$ will, in general, bias the estimate of the wage elasticity.

We use the empirical counterpart of equation (4) to estimate the wage effects of the refugee supply shock and to discuss various identification problems. Our basic empirical regression specification is given by: 4

$$
\Delta \log w_{r s}=\theta_{r}+\theta_{s}-\eta \log \frac{L_{r s 1}}{L_{r s 0}}-\eta m_{r s}+\varepsilon_{r s} .
$$

It is obvious that a key requirement for correctly estimating the wage elasticity $\eta$ is that the residual $\varepsilon_{r s}$ be independent from both the size of the refugee supply shock and from the size of the native response. It is easy to imagine many real-world situations in which such a restriction will fail to hold.

\subsection{Endogenous native labor supply}

A key statistical problem that affects estimates of the wage elasticity arises from the endogeneity of native labor supply. Remarkably, the existing literature has, at best, only superficially addressed the biases created by this type of native response. ${ }^{5}$

\footnotetext{
${ }^{4}$ It is possible to extend the discussion of the labor supply decision by taking into account the probability of finding a job. In that case, we can derive an equation similar to equation (5) for the unemployment rate; see the appendix in Monras (2015b) for such a derivation.
} 
The endogeneity of the change in native labor supply in a particular region-skill cell, $\Delta \log L_{r s}$, can arise due to two distinct factors. First, the amount of labor that native persons already participating in the labor market will offer to employers likely depends on the wage. Put differently, the refugee supply shock affects native labor supply at the intensive margin. Second, the number of natives who choose to offer their services in a particular labor market will respond to changes in the market wage, creating a native response to the refugee supply shock at the extensive margin as well.

Regardless of which margin we are referring to, it is easy to see how endogenous native labor supply contaminates estimates of the wage elasticity by taking a first-order Taylor's expansion of the log change in the size of the native workforce. Equation (5) can then be rewritten as:

$$
\Delta \log w_{r s}=\theta_{r}+\theta_{s}-\eta \frac{L_{r s 1}-L_{r s 0}}{L_{r s 1}}-\eta m_{r s}+\varepsilon_{r s} .
$$

We can then posit a standard model of the labor supply response of natives by writing:

$$
\frac{L_{r s 1}-L_{r s 0}}{L_{r s 1}}=\gamma \frac{M_{r s 1}}{L_{r s 1}}+u_{r s},
$$

where the parameter $\gamma$ measures the native labor supply response. If the refugee supply shock lowers the market wage, the supply parameter $\gamma$ is unambiguously negative as long as the substitution effect dominates the income effect in the neoclassical labor supply framework. In other words, as the entry of refugees lowers the price of leisure, not only do fewer natives work, but those who do remain in the workforce work fewer hours. We can substitute the labor supply response in equation (6) to obtain the reduced form:

5 There are some exceptions. For example, Borjas (2003, Table III) estimates the wage impact of immigration using a regression model that includes a variable giving the number of native workers in the skill group (which is then differenced by adding appropriate fixed effects to the model). However, the properties of the wage elasticities resulting from this particular specification have not been examined in the subsequent literature, despite the widespread adoption of the "skill-cell" approach. Similarly, Monras (2015a) includes the changes in the level of regional GDP and in native labor supplies of the various skill groups in his main regression specification. 


$$
\Delta \log w_{r s}=\theta_{r}+\theta_{s}-\eta(1+\gamma) m_{r s}+\varepsilon_{r s}^{*} .
$$

Equation (7) shows that if we simply exclude the change in the native-born workforce from the estimated regression model (as almost all of studies in the existing empirical literature do), the regression coefficient that relates wage changes to the supply shock measures an amalgam of the wage elasticity $\eta$ and the labor supply parameter $\gamma$. As long as $-1<\gamma<0$, the OLS estimate of the factor price elasticity is biased towards 0 , suggesting that the refugee supply shock had a relatively weak impact on wages. The intuition is obvious: the wage impact of the refugee supply shock is attenuated by the fact that natives supplied less work effort to the labor market, and as a result the real supply shock was not as large as implied by mechanically calculating the number of refugees. Equation (7) also illustrates the interesting case where the displacement effect is one-toone (or $\gamma=-1$ ). The wage change in cell $(r, \mathrm{~s})$ is then uncorrelated with the refugee supply shock because the "complete" native response ensured that there was no supply shock to speak of.

It is worth noting that the magnitude of the supply parameter $\gamma$, which determines the size of the downward bias in estimates of the wage elasticity, depends on how the isolated labor markets $(r, s)$ are defined. For example, Borjas, Freeman, and Katz (1997) documented that the estimated wage elasticity is more negative the larger the geographic size of the labor market (e.g., states as opposed to cities). This result follows easily from equation (7) because it is probably more costly to move across states than across cities (i.e., $\gamma$ is more negative the smaller the geographic area). Similarly, in some contexts it may be sensible to define labor markets in terms of occupations, rather than regions. Because it may be more difficult for natives to switch occupations (implying $\gamma$ is closer to zero), the resulting bias should be relatively small.

\subsection{Endogenous migrant locations}

A positive spurious correlation between $\varepsilon_{r s}$ and $m_{r s}$ may arise because migrants choose in which localities to settle in the receiving country. Suppose that there are two 
regions where the refugees can settle; region 1 is thriving (i.e., wages are growing fast), while region 2 is not. Income-maximizing refugees are then more likely to end up in region 1 , creating a positive correlation between the change in the wage observed in cell $(r, s)$ and the refugee supply shock, and making it more difficult to detect any potential wage depression caused by the supply shock itself.

The search for an instrument that corrects for this specific type of endogeneity dominates the existing discussion of the statistical problems that arise when measuring the wage impact of immigration. Beginning with Altonji and Card (1991), the typical study uses what has become known as the "migration networks" instrument. In particular, Altonji and Card proposed that an instrument for $m_{r s}$ could be the geographic sorting of an earlier wave of immigrants, arguing that the new immigrants would most likely end up in those regions where the earlier immigrants settled because family networks reduce the costs of migration. If labor market conditions in particular areas were not very persistent over time, this means that new migrants enter particular regions for reasons that are unrelated to current labor market conditions. The migration networks instrument has been refined (Card, 2001) by constructing a more sophisticated lag based on national origin: the new immigrants from country $j$ are more likely to settle in those cities where earlier waves of type-j immigrants settled.

It is widely recognized that using a "lagged supply shock" as an instrument is invalid if economic conditions in local labor markets are serially correlated. The initial waves of type-j immigrants chose to settle in region $r$ for a reason (including faster wage growth), and if this reason persists over time, the serial correlation violates the condition that the instrument should be independent of the error term in equation (5).

Although the migration networks instrument is widely used in the literature, very few studies examine the validity of the zero serial correlation assumption. Jaeger, Ruist, and Stuhler (2016) provide a rare and important exception, documenting that the non-zero serial correlation actually found in real-world local labor markets badly contaminates IV estimates of the wage elasticity. The Jaeger-Ruist-Stuhler solution to the serial correlation problem, however, makes exacting data demands, requiring that we observe local labor market conditions for a very long span of time prior to the supply shock. Such data are not 
available in the context of the refugee supply shocks examined in this paper. Instead, the empirical work reported below adopts the approach introduced by Monras (2015). He argues that the combination of a networks instrument together with a supply shock that occurred at time $t$ for truly exogenous reasons (combined with adequate controls for the trend in local economic conditions) provides a "compromise" solution that can help identify the effect of migration even in the presence of serial correlation.

It is worth stressing that this particular endogeneity issue remains a concern even if the cells were demarcated by occupation rather than region. The self-selected refugees will likely have skills marketable in occupations that are in high demand, again creating a spurious positive correlation between the residual in the wage growth regression and the size of the refugee supply shock in a particular market, and biasing the estimate of $\eta$ towards zero. We will use an analogous "employment networks" logic to construct an instrument in this context, arguing that the costs of entering an occupation for a new immigrant are likely to be lower when that occupation has already been penetrated by their compatriots. The compatriots can provide valuable (and cheap) information about job opportunities in particular sectors of the labor market. The empirical analysis reported below uses this alternative approach when analyzing the Israeli labor market, where the small geographic size of the country severely hampers the use of geographic variation.

\subsection{Downgrading of immigrant skills}

A particularly challenging measurement problem arises when the pre-migration skills of immigrants are not a good predictor of the group of native workers with whom they will compete in the receiving country. For example, some of the training that the eventual refugees acquired prior to the move is specific to the country of origin, inevitably leading to a reduction in the stock of human capital that is marketable in the postmigration period. As a result, the observation that a particular refugee supply shock contained many high-skill workers "on paper" does not necessarily imply that it is the highskill natives who will be adversely affected by this shock. As demonstrated in Dustmann, Frattini, and Preston (2013), the classification issues raised by this type of "skilldowngrading" can contaminate estimates of the wage impact of immigration. 
It is easy to determine the nature of the bias by considering the generic regression model that allocates immigrants and natives to specific region-skill cells. To simplify the discussion, suppose that the pre-existing size of the workforce remains constant after the refugee supply shock and that there are two types of workers in each of $r$ regional labor markets: high-skill $(h)$ and low-skill $(u) .{ }^{6}$ The data, therefore, consist of two observations in each of $r$ locations. Equation (5) then implies that the wage change for each of the two types of workers is given by: ${ }^{7}$

$$
\begin{aligned}
& \Delta \log w_{r h}=\theta-\eta \frac{M_{r h}}{L_{r h 1}}+e_{r h}, \\
& \Delta \log w_{r u}=\theta-\eta \frac{M_{r u}}{L_{r u 1}}+e_{r u} .
\end{aligned}
$$

If the pre-migration skills of group $h$ survived the move to the receiving country, equations (8a) and (8b) would correctly specify the regression model that estimates the wage elasticity $\eta$. Suppose, however, that a fraction $\pi$ of the high-skill refugees "lose" their skills during the move. ${ }^{8}$ The true regression model that would correctly estimate the wage impact of immigration is then given by:

$$
\Delta \log w_{r h}=\theta-\eta \frac{(1-\pi) M_{r h}}{L_{r h 1}}+e_{r h}
$$

\footnotetext{
${ }^{6}$ The derivation of the bias would be unaffected if we allowed for changes in native labor supply by using the reduced form specification in equation (7) and reinterpreting the estimate of the wage elasticity as one that nets out the labor supply response.

${ }^{7}$ To simplify the discussion, suppose that the wage growth has been deflated by the observed wage growth observed for each region and for each skill group, so that the regression need not include the vectors of fixed effects $\theta_{r}$ and $\theta_{S}$.

${ }^{8}$ More generally, we can think of $L$ as giving the number of efficiency units of a particular group of pre-existing workers, and $\pi$ would be the rate at which the efficiency units depreciate after the move.
} 


$$
\Delta \log w_{r u}=\theta-\eta \frac{M_{r u}+\pi M_{r h}}{L_{r u 1}}+e_{r u} .
$$

Note that equations (9a) and (9b) correctly measure the size of the refugee supply shock affecting each cell after we account for the skill downgrading.

By algebraically manipulating equations $(9 a)$ and $(9 b)$, we can then rewrite the true regression model as:

$$
\begin{aligned}
& \Delta \log w_{r h}=\theta-\eta \frac{M_{r h}}{L_{r h 1}}-\eta \pi \frac{-M_{r h}}{L_{r h 1}}+e_{r h}, \\
& \Delta \log w_{r u}=\theta-\eta \frac{M_{r u}}{L_{r u 1}}-\eta \pi \frac{M_{r h}}{L_{r u 1}}+e_{r u} .
\end{aligned}
$$

By comparing equations (8a) and (8b) with equations (10a) and (10b), it is easy to see that the downgrading of skills, and the resulting measurement error in the size of the supply shock, effectively adds a regressor to the generic regression model. This additional regressor takes on a value of $\left(-M_{r h} / L_{r h 1}\right)$ for the high-skill labor markets, and $\left(M_{r h} / L_{r u 1}\right)$ for the low-skill labor markets. The coefficient of this additional regressor would equal $-\eta \pi$.

Put differently, the bias introduced by unobserved skill downgrading can be easily reinterpreted as an omitted variable bias, so it should be relatively simple to determine the direction of the bias. A straightforward application of the omitted-variable bias formula (see the Appendix) shows that the OLS coefficient of the refugee supply shock variable resulting from estimating the misspecified model in equations (8a) and (8b) is: ${ }^{9}$

$$
\operatorname{plim} \hat{\eta}=\eta-\eta \pi \frac{\sigma_{h}^{2}}{\sigma_{h}^{2}+\sigma_{u}^{2}}\left[1-\rho_{h u} \frac{\sigma_{u}}{\sigma_{h}}\right],
$$

${ }^{9}$ The derivation of equation (10) assumes that the native workforce is equally split between highand low-skill workers. 
where $\sigma_{s}^{2}$ is the variance in the measure of the supply shock for type $s$ workers across markets; and $\rho_{h u}$ is the correlation between the high-skill and the low-skill supply shocks.

Equation (10) implies that if the refugee supply shock had no effect on wages (so that $\eta=0$ ), the misclassification of some high-skill immigrants into low-skill cells does not generate any bias. The OLS coefficient measuring the wage elasticity will still be zero.

If the true wage elasticity $\eta$ is negative, however, skill downgrading biases the estimated wage elasticity, and the nature of the bias obviously depends on how the highand low-skill supply shocks are distributed across markets. One particularly interesting special case arises when the supply shocks for high-skill and low-skill workers are equally spread out (so that $\sigma_{h}^{2}=\sigma_{u}^{2}$ ). It is then easy to show that the wage elasticity is biased towards zero regardless of the value of $\rho_{h u}$. Another interesting special case occurs when the correlation $\rho_{h u}$ equals zero, so that (roughly) the cities where high-skill refugees end up provide no information about where the low-skill refugees settle. It is obvious from equation (10) that the estimated wage elasticity will again be biased towards zero.

\subsection{Complementarities across skill groups}

Up to this point, our discussion has focused on estimating the impact of a refugee supply shock in a particular region-skill cell on the wage of natives who belong to that same region-skill cell-in other words, the identification of the "own" wage effect of immigration. We have shown that, under certain conditions, the functional form assumption of an aggregate CES production function in a regional labor market produces a very simple regression model that identifies the own wage effect by relating the wage change observed in a particular cell to the refugee supply shock in that cell, even while ignoring the changes that might have occurred in the quantities of other factor inputs. This regression model has become the de facto generic regression in the literature (although it is not often linked to a factor demand theoretical framework).

The entry of the refugees into a particular skill group obviously has ramifications for the wages of workers in other skill groups, and a full accounting of the impact of the supply shock would require documenting not just the own wage effect of immigration, but the "cross effects" as well. Because the number of potential cross-effects explodes as the 
number of skill groups increases, the existing literature, including both the early work of Grossman (1980) and the framework introduced in Borjas (2003), reduces dimensionality by exploiting properties of functional form assumptions about the production technology. For example, Borjas (2003) classifies workers into 32 skill groups (four education groups and eight experience groups). If capital is also a factor input, there are then a potential 1,089 wage effects that need to be estimated. The imposition of a nested CES framework on the data, where various skill groups are aggregated into efficiency units, leads to a remarkable reduction in the number of primitive parameters (i.e., the elasticities of substitution). In Borjas (2003), only three distinct elasticities of substitution are sufficient to derive all 1,089 potential own- and cross-wage effects.

This reduction in the parameter space, however, obviously comes at great cost. Specifically, the nested CES framework greatly limits the types of cross-group complementarities that are allowable. Moreover, the functional form assumptions introduce numerical constraints on the value of the wage effects. For example, a constant returns to scale aggregate production function that has capital and labor efficiency units as inputs must imply that the long-run wage effect of immigration averaged across all skill groups is identically equal to zero. This numerical constraint then cascades over to all other wage effects estimated in such a framework, raising questions about whether the results accurately reflect the underlying data and greatly reducing their value for policy analysis.

To minimize the influence of such extraneous assumptions on the estimated crosseffects of immigration, we only assume the existence of a generalized production function. To simplify the exposition, we consider a production function with two inputs, $F\left(L_{r h}, L_{r u}\right)$, where $L_{r h}$ gives the number of high-skill workers in region $r$, and $L_{r u}$ gives the corresponding number of low-skill workers. ${ }^{10}$ The production function $F$ has the typical properties (i.e., concave, twice differentiable, etc.). If we set the price level as the numeraire, we can then write a general characterization of what happens to wages in region $r$ and skill group $s(s=h, u)$ as:

${ }^{10}$ Assuming more worker types introduces more regressors into the regression model, but does not change the nature of the empirical analysis. 


$$
\Delta \log w_{r s}=\alpha_{s h} \Delta \log L_{r h}+\alpha_{s u} \Delta \log L_{r u} .
$$

where $\alpha_{s j}$ gives the factor price elasticity defined by $\partial \log w_{r s} / \partial \log L_{r j}{ }^{11}$

Instead of imposing functional form assumptions on the production technology, we exploit the fact that the refugees in many of the historical episodes examined in this paper were often concentrated in one particular skill group. Low-skill refuges made up a very large fraction of the Marielitos in Miami and of the Algerian nationals moving to France, while college graduates dominated the influx of Soviet émigrés in Israel. To easily illustrate our approach, suppose that we consider an episode where all refugees belong to the lowskill group. We can then rewrite equation (11) as:

$$
\Delta \log w_{r s}=\alpha_{s h} \Delta \log L_{r h}+\alpha_{s u} \Delta \log L_{r u}+\alpha_{s u} m_{r u},
$$

where the $\Delta \log L_{r s}$ variables are now interpreted as the change in the number of native workers in cell $(r, s)$; and $m_{r u}=M_{r u} / L_{r u 1}$, the measure of the refugee supply shock.

We can then estimate equation (12) separately for each skill group. This methodological approach essentially exploits the natural experiment created by the refugee supply shock to measure not only the own wage effect, but also the cross effects. Put differently, the cross-effects are identified by relying on the exogenous nature of refugee supply shocks and on the historical concentration of the refugees in a very small number of skill groups. The cross effect is given by the coefficient that relates the labor market outcomes of skill groups untouched (at least directly) by the refugees to the measure of the supply shock in the skill group that was most directly affected by the political upheaval.

${ }^{11}$ A simple derivation of (11) starts with the fact that the marginal productivity condition (say, for high-skill workers) is $w_{r h}=F_{h}\left(L_{r h}, L_{r u}\right)$. Totally differentiating the first-order condition yields: $d w_{r h}=F_{h h} d L_{r h}+F_{h u} d L_{r u}$. Equation (11) then follows easily from this differential, where the factor price elasticity $\alpha_{i j}=\kappa_{i} c_{i j} ; \kappa_{i}$ is the share of income accruing to skill group $i$; and $c_{i j}$ is the elasticity of complementarity $\left(c_{i j}=F_{i j} F / F_{i} F_{j}\right)$ between groups $i$ and $j$. 
It is important to re-emphasize that this approach does not impose any constraints on the potential value of the cross-effects. In fact, we can even use equation (12) to reestimate the own-effect without imposing the aggregate CES functional form restriction used to derive equation (5). The regression implied by equation (12), therefore, effectively lets the data decide what impact refugees had on the earnings of all native groups.

\subsection{Other problems}

In an ideal (from a researcher's point of view) supply shock, the migrants would be randomly selected from the population of the sending country. However, it is hardly ever the case that migrants are a random sample of that population. For example, FernandezHuertas (2011) documents that Mexican workers moving to the United States tend to be less skilled than the Mexican workers who choose to remain behind. Although this type of selection may be due to a variety of factors, Borjas (1987) shows how differences in the returns to skills between the sending and receiving countries can systematically generate various patterns of selection.

Even in the context of exogenous refugee supply shocks, the political change in the sending country inevitably affects different types of people differently. Those who benefit from the new regime will be more likely to stay behind, while those who lose will have greater incentives to become refugees. For example, a Communist takeover "taxes" the economic well being of entrepreneurs. If the receiving country values those types of skills, the self-selection of the refugees creates a spurious positive correlation between the residual $\varepsilon_{r s}$ in equation (5) and the share of refugees entering those markets, $m_{r s}$. This positive correlation would further attenuate the estimate of the wage elasticity $\eta$. Although it is recognized that the self-selection of immigrants contaminates the measured wage impact of immigration, there have not been any studies that attempt to quantify this bias.

In addition, the supply shock might generate "general equilibrium" effects because the refugees might influence the average level of productivity in the aggregate economy. One such effect that has received some attention is the possibility that some immigrants, and particularly high-skill immigrants, bring new ideas and knowledge that expand the production frontier. Specifically, the high-skill immigrants not only introduce increased 
competition with high-skill natives, but also create knowledge spillovers that increase the productivity of all other workers in the process.

Unfortunately, the typical attempt to estimate the impact of supply shocks on the average wage level in a receiving country has again relied on extraneous functional form assumptions about the production technology. This approach builds in a numerical answer for the general equilibrium wage effects. In the absence of productivity spillovers, for example, if the aggregate production function were Cobb-Douglas, the elasticity relating the average wage level to the size of the workforce must equal (the negative of) capital's share of income in the short run and zero in the long run.

The reliance on functional form assumptions to quantify the general equilibrium effects is not surprising. The estimation of these aggregate effects from actual data raises extremely difficult challenges. How exactly would one estimate the impact of a supply shock on the average wage level from available data? Suppose that we observe that a country receiving more refugees is doing better post-shock than it was pre-shock. Is this due to what migrants bring to the receiving country, or is it possible that there are other unobserved factors, unrelated to immigration, that are determining economic growth in that country? Making before-and-after comparisons in the average wage of a country provides very little information about how the refugee supply shock affected the overall level of economic activity.

In sum, our discussion shows the importance of thinking carefully about both the underlying theoretical model and the statistical problems created by real-world supply shocks when we attempt to measure the labor market impact of immigration. In one sense, the measurement of the wage impact of refugee supply shocks is a trivial exercise. The canonical model of supply and demand, which is fundamental to our understanding of how real-world labor markets work, predicts that the refugees will obviously lower the wage of competing native workers in the short run. To conduct yet another study documenting that labor demand curves are downward sloping, therefore, would seem to be a rather pedestrian exercise.

It turns out, however, that measuring the elasticity of wages with respect to migrant inflows introduces thorny measurement and statistical problems that have yet to be fully resolved. In fact, labor economists have devoted a disproportionate amount of time and 
effort in the past three decades to document what is, in the end, a trivial empirical finding. The resulting confusion (and sometimes obfuscation) in the literature has not been a productive contribution to the immigration policy debate.

The examination of refugee supply shocks-which are truly exogenous on at least some dimensions-can perhaps help clarify and increase our understanding of how immigration affects real-world labor markets. The real-world conditions that generate refugee supply shocks will almost never replicate the idealized conditions that lead to the generic empirical approach that is widely used in the literature. As we have seen, however, many of the statistical problems created by real-world circumstances tend to bias estimates of the wage impact of immigration in the same direction: attenuating the negative wage effect predicted by factor demand theory.

\section{Mariel}

On April 20, 1980, Fidel Castro declared that Cuban nationals wishing to emigrate could leave freely from the port of Mariel. Cuban-Americans living in the United States quickly organized a boatlift to bring their relatives. The first migrants arrived on April 23, and over 100,000 had taken advantage of Castro's invitation by June 3. By the time the boatlift ended through an agreement between the US and Cuban governments in October 1980, about 125,000 Cubans had moved and Miami's workforce had grown by about 8 percent. The Marielitos were disproportionately low-skill, with most lacking a high school diploma. The Mariel supply shock increased the size of this low-skill workforce in Miami by nearly 20 percent.

We begin our empirical analysis of refugee supply shocks by reexamining the Mariel data from the perspective of the factor demand framework introduced earlier. The Mariel context plays a prominent role in the literature that examines the wage impact of immigration. Card's (1990) landmark study of this particular supply shock was a pioneer in the now-common approach of examining outcomes from natural experiments to measure parameters of great policy interest.

The Card study looked at labor market conditions, including wages and unemployment, in Miami in the years before and after Mariel, and compared the change in 
those variables to what was happening in comparable cities that were presumably unaffected by the refugees. Surprisingly, this comparison indicated that the relative wage for the average worker in Miami remained unchanged, leading Card to conclude that even sizable supply shocks had little effect on the price of labor in the affected markets.

There has been a flurry of renewed interest in the Mariel supply shock in the past year, sparked by the Borjas (2017) reappraisal of the Mariel evidence. ${ }^{12}$ Using a key lesson from the voluminous research in the past two decades on the labor market impact of immigration, Borjas argued that it is crucial to study the impact of the Marielitos by focusing specifically on the earnings of the workers most likely to be affected by the supply shock-namely, the low-skill workforce. It turns out that the comparison of low-skill wages in Miami and various control cities before and after Mariel overturns the perception that Mariel had a negligible effect, showing instead that the relative earnings of male high school dropouts in Miami fell and that the magnitude of the wage drop was substantial.

\subsection{Summary Statistics}

Table 2 summarizes the available data on the size and skill composition of the Mariel supply shock. The Cuban refugees began to arrive only a few weeks after the 1980 decennial census was conducted, so that the first enumeration of the Marielitos in largescale surveys was not done until 1990. Specifically, the 1990 census reports the number of

12 See Peri and Yasenov (2015) and Borjas (2016). The empirical debate hinges on whether women and non-Cuban Hispanics should be included in the sample when calculating the average wage in a local labor market. Borjas (2016) notes that the inclusion of women is problematic because the female labor force participation rate was rising rapidly in the 1980s, and it grew differentially in different metropolitan areas. The inclusion of women then inevitably changes the sample composition over time, contaminating wage trends. Similarly, nearly half of the additional observations that would be added by including non-Cuban Hispanics in the sample are of immigrants who arrived after Mariel, again changing the sample composition and contaminating wage trends in local labor markets. Finally, the original draft of the Peri and Yasenov (2015) study examined a sample of workers aged 16-61 without any controls for whether a particular person was enrolled in school. This led to the erroneous classification of high school students aged 16-18 as "high school dropouts" because those students had not yet received their high school diploma. It is worth noting that the possibility that Card's evidence does not correctly convey what happened to the low-skill labor market in Miami was first noted in the online appendix of Monras (2014), which examined wage trends in the pooled sample of high school dropouts and high school graduates and documented a relative decline in the wage of Miami's low-skill workforce. 
Cuban-born persons who moved to the United States during the years 1980 or 1981.13 We define this group to be the population of refugees resulting from the Mariel supply shock.

The 1990 census enumerated 120,605 such immigrants. That census also reports the geographic location of the refugees as of 1985, with 69.4 thousand of the Marielitos (or almost 60 percent) living in Miami five years after the shock. Note that although all existing studies of the impact of the Mariel supply shock focus on labor market outcomes in the Miami metropolitan area relative to some set of placebo cities, 40 percent of the Marielitos were living outside the Miami area within 5 years after the shock. The main alternative locations were New York City (which housed 13 percent of the refugees), Los Angeles (7 percent), and Tampa (3 percent). ${ }^{14}$

The regression framework derived earlier allows for the Marielitos to have an impact on cities other than Miami. This fact marks one key distinction between our regression-based approach and the treated-untreated difference-in-differences methodology employed in both the Card (1990) and Borjas (2017) studies. We discuss the implications of this methodological distinction in greater detail below.

Table 2 also confirms the insight that motivated the Borjas (2017) reappraisal. The Mariel supply shock was composed of disproportionately low-skill workers. Over 60 percent of the refugees lacked a high school diploma, as compared to only 20 percent of the native-born workforce in Miami. In contrast, only 7 percent of the Marielitos had a college diploma, as compared to over 25 percent of native workers. As a result, even though the Marielitos increased Miami's population by only 8 percent, they increased the number of male workers without a high school diploma by 32 percent.

13 The data from later surveys, including the 2000 decennial census, indicate that the number of Cuban immigrants who arrived in 1981 is relatively small, so that this definition of the Marielitos should not create substantial measurement error; see the detailed discussion in Borjas (2017).

14 We identify the 1985 locations from the 1990 census data both because of the larger sample size of the decennial census and because the census specifically identifies persons born in Cuba (as opposed to having Cuban ancestry, which is the only information available in the CPS). To further increase the precision of our measure of the supply shock, we remove other immigrants arriving in the United States between 1980 and 1985 from the base population in each cell. Specifically, we measure $m_{r s}=C_{r s 1} /\left(L_{r s 1}-C_{r s 1}-I_{r s 1}\right)$, where $C_{r s}$ gives the number of Marielitos in cell $(r, s) ; I_{r s}$ gives the number of "other" immigrants who arrived in 1980-85; and $L_{r s 1}$ gives the size of the cell in 1985. The regression results are almost identical if we do not exclude the other immigrants from the base. 
The bottom panel of Table 2 reports the rate of wage growth during the relevant period for each education group, both in Miami and outside Miami. We use the March CPS data to calculate the pre- and post-Mariel average log wage in a sample of non-Hispanic men aged 25-59. ${ }^{15}$ We pool workers who reported earnings data in calendar years 1977-79 to calculate the average pre-Mariel wage, and pool data for calendar years 1981-84 to calculate the post-Mariel wage. We do not use earnings data from the 1980 calendar year because the Marielitos arrived towards the middle of that year.

The summary statistics reported in the bottom panel of the table shows that the rate of wage growth for high school dropouts was far lower in Miami than outside Miami. Interestingly, the table also shows that the rate of wage growth for high school graduates, a group whose size was only increased modestly by the Marielitos, is noticeably higher in Miami than outside Miami. Similarly, the unemployment rate of high-skill workers decreased in Miami, while increasing in the rest of the country. These patterns hint at the possibility that refugee supply shocks generate not only adverse own wage effects, but also improve labor market conditions for complementary workers, a result that was overlooked in earlier studies.

\subsection{Results}

We initially use the regression models derived in equations (5) and (7) to identify the own effects of the Mariel supply shock. The analysis uses the sample of 38 metropolitan areas, including Miami, which can be consistently matched over the 1977-1984 period. ${ }^{16}$ We classify workers into four education groups: high school dropouts, high school graduates, some college, and college graduates. ${ }^{17} \mathrm{We}$ examine the labor market outcomes of non-Hispanic men aged 25-59, a group that approximates the prime-age native-born

\footnotetext{
15 Our empirical analysis of all four refugee episodes focuses on examining labor market outcomes for prime-age men. This is the group of workers most attached to the labor market, so that wage and employment trends are less likely to be contaminated by changes in sample composition.

16 We use the aggregated 3-digit version of the metarea variable in the IPUMS files (rather than the 4 -digit version that would generate a sample of 44 metropolitan areas) to avoid including in the analysis local labor markets that have very few observations.

17 The unit of observation that defines a market could be further refined to a city-education-age cell. Such a definition, however, leads to a very small average number of observations per cell in the refugee shocks examined in this paper.
} 
workforce in Miami, the city most affected by the Marielitos, around 1980. The unit of observation in the regressions is a city-education cell, so that the identifying variation arises both from the fact that the Marielitos settled in a specific set of locations and were disproportionately represented in the least-skilled group.

Table 3 reports the regression coefficients that estimate the own effect of the Mariel supply shock. Throughout the analysis, the regressions are weighted by $\left(n_{1} n_{0}\right) /\left(n_{1}+n_{0}\right)$, where $n_{t}$ gives the number of observations used to calculate the dependent variable in a particular city-education cell at time $t .{ }^{18} \mathrm{As}$ implied by the theory-based regression specification in equations (5) and (7), all the regressions include education fixed effects and metropolitan area fixed effects. ${ }^{19}$ We use three alternative dependent variables: the rate of wage growth in a city-education cell (where the wage variable measures weekly earnings); the change in the average unemployment rate (where the unemployment rate is defined as the ratio of the number of persons unemployed to the number of persons in the labor force); and the change in the average employment rate (defined as the ratio of the number of employed to the size of the corresponding population).

It is useful to begin by discussing the regression coefficients from the simplest OLS specifications reported in the first two columns of Panel B of the table, where the dependent variable is the change in the average log weekly wage. The theory-based specification derived earlier requires the inclusion of the variable $\Delta \log L_{r s}$, regressor that gives the log change in the size of the native workforce in the cell. The table reports coefficients from two alternative regression models that address the endogeneity of this variable in different ways. First, we simply exclude the variable from the regression so that the estimated wage elasticity is a reduced form coefficient that incorporates the native labor supply response (and is biased towards zero) Alternatively, we replace the variable $\Delta$

\footnotetext{
18 These are the optimal weights when constructing aggregated first-differenced cells from microlevel data. The variance of the differenced average residual (assuming the variance of the person-specific error term is not serially correlated and has constant variance) is given by $\left(\sigma_{\varepsilon}^{2} / n_{0}+\sigma_{\varepsilon}^{2} / n_{1}\right)$. The optimal weight takes into account the fact that measurement error of the mean value in the cell is less accurate if the number of observations in that cell is small.

19 The inclusion of these fixed effects do not saturate the regression because the nature of the Mariel supply shock led to very unbalanced supply shifts across both cities and education groups.
} 
$\log L_{r s}$ with the corresponding change in the native-born population in that cell, so that the coefficient of this variable itself becomes a type of reduced-form coefficient. ${ }^{20}$ Note that the coefficient of the variable measuring the size of the Mariel supply shock is about -1.3, and statistically significant, regardless of how we address the endogeneity of the native labor supply response. ${ }^{21}$ Figure 1 helps visualize the wage impact of the Marielitos. It is clear that the negative own wage effect is driven mostly by the changing market conditions facing low-skill workers in the very small number of cities where most of the refugees settled.

A crucial feature of the Mariel supply shock is that the refugees could only leave from the port of Mariel. Many of the Cuban-Americans who already lived in the United States bought or rented boats they would then take to Mariel to pick up their relatives (as well as other potential refugees) waiting at the port. It is inevitable that the geographic sorting of the new arrivals would be very similar to that of the pre-existing Cuban population in the United States, a group that sponsored and physically enabled the entry of the Marielitos. Given the extreme clustering of the pre-Mariel Cuban refugees in the Miami metropolitan area, with about 50 percent of that population living in Miami in 1980, it is not surprising that about 60 percent of the Marielitos ended up there as well.

We address the potential endogeneity created by the geographic distribution of the Marielitos by using the geographic sorting of the pre-Mariel Cuban immigrants to predict where the new refugees would settle. 22 The first panel of Table 3 shows the relevant coefficient from the first stage regression, summarizing the relation between the size of the Mariel supply shock in cell $(r, \mathrm{~s})$ and the share of Cubans in that cell prior to 1980. Not surprisingly, the coefficient is strongly positive. ${ }^{23}$

20 This reduced-form specification implies that the regression coefficient of the refugee supply shock will generally differ from that of the change in the population of the specific cell.

21 The wage elasticity estimated in the regression framework is very similar to the -1.5 elasticity produced by applying a difference-in-differences approach to the March CPS data; see Borjas (2017).

22 We use data from the 1980 census to calculate the distribution of pre-Mariel Cubans across the region-skill cells.

${ }^{23}$ In other words, we use the lagged share of Cubans in the workforce as the instrument. The firststage regression coefficient then essentially estimates by how much the pre-existing immigrant workforce in a given cell increased the supply of migrants to that cell as a result of the refugee shock. Some studies in the literature (e.g., Ottaviano and Peri, 2007) use the predicted location of the actual flows observed in the data. If the instrument is sufficiently strong in these alternative IV specifications, the first-stage coefficient, by construction, will hover around 1.0. 
The IV estimates of the wage elasticity reported in the second panel are again about -1.3 , so that there is little indication that controlling for the endogeneity of the geographic sorting of the refugees plays any role in determining their labor market impact. ${ }^{24}$ The similarity between the OLS and IV estimates in the Mariel context is not surprising. The physical characteristics of the boatlift ensure that the geographic sorting of the Marielitos after arrival had little to do with economic conditions circa 1980.

The bottom two panels of the table report analogous regressions using the change in the unemployment and employment rates as dependent variables. None of the coefficients are significantly different from zero. The own effects of the Mariel supply shock, therefore, seem to be restricted to changes in wages. This finding may perhaps be informative about how labor markets adjust to supply shocks during a period of very high inflation. The US inflation rate was 13.5 percent in 1980 and 10.3 percent in 1981.

Table 4 reports selected coefficients from the more comprehensive regression model that identifies both own- and cross-effects. We can carry out this analysis because most of the Marielitos were high-school dropouts, allowing us to examine their impact on the other skill groups. To do so, we estimate equation (12) separately in each of the four education groups used in the analysis (i.e., high school dropouts, high school graduates, some college, and college graduates). The regression model also includes variables measuring the change in the native population in each of the groups. This regression specification enables us to detect potential complementarities across factor types without imposing any functional form restrictions on the production technology.

As before, the estimated own wage effect is negative and significant, with a wage elasticity of about -0.9 . Similarly, the estimate of the own employment effect is not distinguishable from zero. ${ }^{25}$ The analysis, however, shows that the cross effects are numerically important. Although the supply shock of the predominantly low-skill

\footnotetext{
24 We also estimated the Mariel regressions using data from the Outgoing Rotation Group (ORG) CPS files rather than the March CPS, and obtained similar results, although, as in Borjas (2017), the point estimate of the own wage elasticity is smaller. The own wage elasticity estimated in the ORG when the regression model includes the change in the size of the native population is $-0.51(0.11)$ in the OLS regression, and -0.43 $(0.16)$ in the IV regression. These elasticity estimates are again virtually identical to the -0.5 elasticity implied by applying a difference-in-differences methodology to the ORG data.
}

25 The instrument in this regression uses only variation in the location of the least-skilled Cubans. 
Marielitos lowered the wage of high school dropouts, it raised the wage of workers with a high school education, and this effect is both numerically and statistically significant. The cross-wage elasticity is about +0.7 . In addition, the unemployment rate of workers with more than a high school diploma also fell significantly.

In sum, our analysis of the Mariel supply shock yields a remarkable result. As implied by the simplest model of factor demand in a competitive market, supply shocks can have both negative and positive effects on the pre-existing workforce. Those workers who most resemble the refugees suffer the wage loss, while the wage gains accrue to those workers who complement the skills brought in by the refugees.

The data also indicate that the negative and positive effects of supply shocks need not occur along the same dimensions. In the Mariel context, the own effects tend to show up as wage cuts, while cross effects are observed in both wages and employment. There is obviously much to learn about how labor markets adjust to supply shocks. Regardless of how the market reaches a new equilibrium, however, it is evident that refugee supply shocks can have important distributional consequences.

\subsection{Alternative Approaches to Natural Experiments}

It is of interest to contrast the results summarized in Tables 3 and 4 with the evidence reported in existing studies of the Mariel supply shock. As we noted earlier, there is a key methodological difference between our theory-based regressions and the atheoretical approach exemplified in earlier studies. Both Card (1990) and Borjas (2017) pursued a difference-in-differences approach, comparing the changed conditions in the Miami labor market to the changed conditions in a set of control cities.

It is obviously very difficult to construct perfect control groups or "placebos" outside a laboratory setting. A good placebo needs to satisfy two distinct conditions. First, the treated and control groups must be comparable in important ways. Card (1990) compared Miami to a control group of four cities: Atlanta, Houston, Los Angeles, and Tampa. This particular placebo was partly selected by looking at employment dynamics in various cities both before and after the Mariel supply shock. The Borjas (2017) reappraisal showed that the construction of the control group plays a key role in any evaluation of the impact of the Marielitos. Using an alternative control group based on employment trends prior to the 
supply shock, as well as employing the Abadie, Diamond, and Hainmueller (2010) synthetic control method, consistently resulted in larger (i.e., more negative) estimates of the own wage effect of the supply shock.

A second condition that a good placebo must satisfy is that there should not be any spillovers between the treatment and control groups. This condition, although conceptually important, has been ignored in all existing Mariel studies. It is trivial to see how such spillovers arise in this context. Nearly 40 percent of the Marielitos chose to settle in cities outside Miami. In fact, two of the cities in the control group used in Card's (1990) study were cities that actually received many refugees: 7.4 thousand settled in Los Angeles and another 3.1 thousand settled in Tampa. The generic difference-in-differences approach, therefore, suffers from the fact that some of the cities in the control group were treated by the exogenous supply shock as well.

Unlike the traditional difference-in-differences calculations that compare Miami and a placebo, our regression-based analysis allows for the refugee supply shock to affect many different markets, along both the region and skill dimensions. We identify the impact by exploiting the different numbers of Marielitos settling in different cities and the different numbers of Marielitos in different education groups. In other words, the regression approach fully incorporates the fact that the refugee supply shock "treated" many markets, and in fact treated those markets differentially, and then uses that dispersion to identify how supply shocks alter labor market outcomes.

\section{5. Émigrés to Israel from the former Soviet Union}

Prior to the late 1980s, it was extremely difficult for Soviet Jews to migrate to Israel. ${ }^{26}$ The pressures for such migration began soon after the Six-Day War in 1967, when Israel began to more forcefully state its demand that Soviet Jews be allowed to rejoin their families or build a new life in Israel. The Soviet reluctance to allow such migration became an important obstacle in attempts to improve relations between the Soviet Union and the

${ }^{26}$ See Buwalda (1997) for a detailed history. 
West, and it was not until Michael Gorbachev's Glasnost initiative in 1986 that the Soviet Union began to consider and allow the emigration of its Jewish population.

In 1986 and 1987, a small number of visas were granted to Soviet Jews who wished to emigrate. Most of these émigrés, however, chose to settle in the United States or Canada, and only a small fraction moved to Israel. The United States was a particularly appealing destination because the country allowed Soviet emigrants to qualify for refugee status, making it relatively easy to obtain entry visas.

By 1989, the United States had changed the rule that automatically classified Soviet émigrés as refugees, making it almost impossible for Soviet Jews to move to that country unless an American relative could sponsor their entry. In contrast, Israel's Law of Return continued the open-door policy of welcoming all Jews. As Friedberg (2001) notes: "Between 1989 and 1995, 610,100 immigrants arrived from the [former Soviet Union], increasing the size of the Israeli population by $13.6 \%$."

\subsection{Summary Statistics}

We use data drawn from the 1983 and 1995 Israeli census microdata maintained by IPUMS. Each of these data files represents a 10 percent random sample of the Israeli population. The censuses report information on country of birth and the year of migration (if born abroad). Using the 1995 census, we classify a Soviet émigré as someone born in the former Soviet Union who migrated to Israel between 1990 and 1995. For expositional convenience, we will refer to the pre-existing population of Israeli citizens as "natives" even though a very large fraction (42 percent) was born outside Israel. As Table 5 shows, the Soviet émigrés made up almost 10 percent of the population in $1995 .{ }^{27}$

The table also summarizes key characteristics of the Soviet émigrés. In contrast to the Marielitos, the émigrés were very highly skilled. Few of them (only about 11 percent) lacked a secondary education, as compared to a third of the Israel population. In contrast,

27 The inflow of Soviet émigrés was so large that we measure the size of the shock as $m_{k}=$ Soviet $_{k} /\left(L_{k 1}+\right.$ Soviet $\left._{k}\right)$, where Soviet $k$ gives the number of émigrés in cell $k$. The point estimates of the wage impact do not change significantly if we exclude the number of émigrés from the denominator, but the IV coefficient is less precisely estimated. This is probably because the derivation of our estimating equation uses the approximation that the refugee supply shock is "small," an assumption that is false for many cells in the Israeli context. 
43 percent of the émigrés had completed a university education, as compared to only 18 percent of the Israeli natives.

The table documents interesting differences between the occupational distributions of the émigré and native populations. Note that 14 percent of the émigrés, despite their very high educational attainment, ended up as "unskilled workers," even though only 7 percent of the native Israeli population worked in such jobs. Similarly, over 50 percent of the émigrés worked as "skilled workers in industry and construction," again a far higher representation than the 35 percent of natives in that occupation. ${ }^{28}$

The bottom panel of the table presents summary statistics giving the wage growth of native Israelis observed in selected education/occupation categories. We examine the change in annual earnings (the only wage measure that is available in both Israeli censuses). It is suggestive that the education-occupation cell that was most affected by the Soviet émigrés, university graduates who end up as "skilled workers in industry and construction," experienced a remarkably large drop in earnings during the period.

We will show below that this mismatch between the pre-existing skills of the émigrés (as measured by their educational attainment) and the type of job they actually ended up doing in Israel may have played an important role in generating Friedberg's (2001) conclusion that the émigrés did not affect the Israeli wage structure. A reexamination of the data that allows for the very high-skill émigrés to influence the earnings of workers employed in occupations that typically employ low-skill workers (and hence workers with lower education levels) overturns this result and demonstrates that the émigrés indeed adversely affected the wage of "truly competing" workers, and likely increased the wage of complementary workers.

\subsection{Results}

Israel is a small country; its land size is roughly the size of El Salvador or New Jersey. As a result, it makes little sense to define a labor market in terms of a region-skill classification. The short commuting distance from one city to another would generate

\footnotetext{
28 The full name of the occupation is "skilled workers in industry, and construction, and other skilled workers."
} 
sufficient spillovers across markets to make it difficult to measure the impact of a supply shock by exploiting dispersion at the regional level. Not surprisingly, Friedberg's (2001) examination of the Soviet supply shock focused on the impact of the émigrés on wages across occupations, so that these "markets" are less likely to be affected by the spillovers resulting from native internal migration.

Although we adapt Friedberg's choice of an occupation (rather than a local labor market) to define the relevant unit of analysis, our analysis differs in a crucial way. As the summary statistics reported above suggest, the educational attainment of the émigré provides an additional measure of skills that is likely to affect productivity and wageseven if the émigrés must initially work in jobs that do not reflect their credentials. Therefore, we define a labor market as a particular occupation-education pairing. We classify workers into four education categories: less than primary schooling, completed primary schooling, completed secondary schooling, and completed a university education. ${ }^{29}$ We also use the occupation classification available in the IPUMS files of the Israeli census, which are the eight broad occupation groups listed in Table 5. As in our study of the Mariel supply shock, we restrict the empirical analysis to male Israeli natives aged 25-59. Finally, the nature of the Israeli census data implies that we can only use the change in log annual earnings as the dependent variable. The occupation of employment is only available for persons who work so that we cannot analyze the impact of the supply shock on either the employment or the unemployment rate.

Table 6 summarizes the main regression results using the simpler specification that focuses on identifying the own wage effects. Consider initially the OLS results in the first two columns of the bottom panel. The estimated coefficient is about -0.73 (with a standard error of 0.27 ). Note that the estimate of the wage elasticity of about -0.7 is unchanged when we add a regressor giving the change in the size of the native population in the particular cell.

The table also reports the wage effect resulting from the IV specification. The instrument is the share of earlier Soviet migrants (who were observed in the 1983 census) employed in a particular occupation-education pairing. The key coefficient in the first stage

${ }^{29}$ Friedberg (2001) examines the education-adjusted wages of workers in a particular occupation. 
of the IV is highly significant, so that the new émigrés found employment in roughly the same occupations that employed the compatriots that arrived prior to the collapse of the Soviet Union. The IV estimate of the wage elasticity is $-0.62(0.32)$, very similar to the coefficient obtained in the OLS regression. In short, a regression analysis based on the notion that a labor market consists of an occupation-education cell unambiguously indicates that the Soviet émigrés adversely affected the earnings of comparable workers.

Figure 2 visualizes this insight. The figure shows a large "cloud" of occupationeducation cells that were unaffected by the Soviet influx. It also shows that the relatively few cells that "welcomed" the émigrés are the source of the negative wage effect. The affected cells are composed of the select occupations that attracted high-skill émigrés. Not surprisingly, those occupations were the ones that experienced the lowest wage growth between 1983 and 1995. ${ }^{30}$

As shown in Table 5, the size of the Soviet supply shock was largest for workers who had a university degree. For this particular skill group, the inflow of the refugees represented a 26 percent increase in supply. As with our analysis of the Mariel supply shock, we exploit this fact to derive a simple method for estimating the potential crosseffects. Specifically, we estimate the cross-effects model given by equation (12) separately for each of the education groups, where the key regressor gives the supply shock experienced by university graduates in a particular occupation group. ${ }^{31}$

Table 7 reports IV regression coefficients from the cross-effects specification. The results again indicate that the own-effects of the high-skill Soviet émigrés are negative, implying a wage elasticity of about -0.7. The table also reveals, however, that there were some positive complementarities between the high-skill émigrés and the least skilled Israeli natives who had not completed their primary education. The earnings of the lowest

\footnotetext{
30 There was a currency change in Israel in 1986, one year after the 1985 census that we use to establish the baseline in the pre-shock period. The wage data in 1985 is denominated in Shekels while the post-shock period data is denominated in New Shekels. Therefore, the vertical axis in Figure 2 reflects both the change in the currency as well as real wage growth. Our analysis examines relative differences across education-occupation cells. The currency change is absorbed by the constant in the regressions.

31 The regression also includes a variable that controls for the change in the size of the native population in the "own" occupation-schooling group. Because of the small number of observations within each education group, we exclude the "cross" changes in native labor supply. The results reported below would be very similar if, instead, we aggregated the data to two education groups and included both the ownand cross- native supply responses.
} 
education group increased after the refugee supply shock, with a cross-elasticity of +0.35 (0.18).

Note also that the refugee supply shock had, if anything, a slight negative impact on the earnings of intermediate skill groups.. The coefficients that measures the cross wage elasticity between the high-skill émigrés and the middle-skill Israelis are about -0.1 (though not significant). This result is likely to be a consequence of the skill downgrading that many Soviet émigrés encountered after they entered the Israeli labor market, an issue we discuss in much greater detail shortly. The skill downgrading obviously implies that some high-skill émigrés were competing in the same labor market as lower-skilled natives, so that the cross-effects measured by the regressions reported in Table 7 actually incorporate an "own effect" on the intermediate skill groups as well. But it is unlikely that the skill downgrading cut the efficiency units of a college-educated Soviet émigré to that of an Israeli native who had not completed a primary education, explaining why it is the least skilled Israeli natives who gained from the Soviet supply shock.

These results are comparable to the ones obtained in the Mariel context. The entry of the low-skill Marielitos increased the wage of natives who were more highly skilled, while the entry of the high-skill Soviet émigrés increased the wage of natives who were least skilled. These cross-effects document the potentially large distributional consequences that refugee supply shocks can have on the receiving country's labor market.

\subsection{Skill Downgrading}

In important ways, the evidence summarized in Table 6 is both similar to and very different from the evidence reported in Friedberg (2001), the study that has most carefully examined the consequences of this specific supply shock. As we noted earlier, the Friedberg analysis uses an occupation as the unit of analysis and examines the trend in educationadjusted wages within an occupation. Friedberg also reports both OLS and IV estimates of the own wage effect attributable to the Soviet influx.

In fact, the own wage effects that Friedberg estimated in her OLS regressions are very similar to those reported in Tables 6 and 7, showing a significant reduction in the wage of those occupations most affected by the Soviet émigrés. For example, Friedberg (1990, Table II) reports an own wage elasticity of -0.616 (0.206). Friedberg then argued 
that the occupational sorting of the new émigrés in Israel was endogenous, as incomemaximizing émigrés would obviously gravitate towards the highest-paying occupations.

To control for this endogeneity, Friedberg used the migrant's occupation in the Soviet Union, prior to migration, as an instrument for the migrant's eventual occupation in Israel, arguing that the pre-migration occupational choice was obviously unaffected by the Israeli wage structure. The use of this particular instrument, which is available in a small survey of Soviet émigrés used by Friedberg but is not available in the IPUMS files, leads to an IV estimate of the wage elasticity that is positive and insignificant, leading her to conclude that "the influx of Russians to a given occupation in Israel does not appear to have adversely affected the wage growth of natives working in that occupation" (Friedberg, 2001, p. 1395).

It is important to emphasize that the difference between the OLS and IV results in the Friedberg study is puzzling, and remains unexplained. ${ }^{32}$ As long as émigrés are incomemaximizers, entering the most profitable occupations, the endogeneity created by the selfsorting of the émigrés into high-paying jobs should bias the OLS coefficient towards zero. In short, Friedberg's correction for this type of endogeneity should have presumably led to a more negative wage elasticity, and not to a more positive one.

Table 6 shows that our IV estimate of the wage elasticity remains negative and significant, and is, in fact, about the same magnitude as the OLS coefficient. There is a crucial difference, however, between the two instruments: Friedberg's instrument is based on the occupation that the Soviet émigrés held in the Soviet Union prior to migration; our instrument is based on the actual occupations that earlier waves of émigrés with similar education pursued in Israel.

The difference in the estimates of the wage elasticity implied by the two different instruments is, of course, related to the possibility that the skills the émigrés acquired in the Soviet Union may not be completely transferable to the Israeli labor market. In fact, it is easy to document that the pre-existing skills of the émigrés are not a very good predictor of the type of job they actually end up doing.

32 Cohen-Goldner and Paserman (2011) make a related point, arguing that Friedberg used a weak instrument that led to an understatement of the wage impact of the émigré supply shock. 
Table 5 also reports the occupation distributions of the émigrés and natives who have a university degree. Recall that half of the émigrés are in this particular education category. The table clearly shows a substantial downgrading in the type of job that a highskill émigré held in Israel. Only one percent of native university graduates, for example, end up as "unskilled workers." Among émigrés, however, the probability of working in such jobs increases ten-fold. Only four percent of native university graduates end up being "skilled workers in industry and construction." Among the émigrés, however, the probability increases 9-fold, to 36 percent. In short, the data clearly indicate that preexisting educational skills, although obviously correlated with the type of job that the émigrés will do in Israel, can generate very large errors in predicting the post-migration allocation of émigrés across occupations. The obvious skill downgrading can help explain not only the different wage elasticities produced by the two instruments, but also the puzzling result in the Friedberg study where the use of instrumental variables leads to a more positive wage elasticity.

Consider the specific example where fluency in Hebrew represents a barrier into certain occupations. For instance, suppose there are two occupations in Israel, one where workers need to be fluent in Hebrew (e.g., a TV personality) and one where workers do not (e.g., working at a manufacturing assembly line). As a result of the difference in language requirements, the typical Soviet émigré, even though he might hold a university degree, will inevitably end up in occupations where Hebrew fluency is unimportant.

In fact, it is easy to document that type of sorting in the Israeli labor market. The 1983 Israeli census reports whether Hebrew was a first language for each enumerated person. We can construct a measure of the share of workers who have Hebrew as a first language (excluding migrants from the Soviet Union) in each occupation-education cell. Figure 3 reveals a strong negative relationship between the size of the Soviet supply shock in each cell and the fraction of people who speak perfect Hebrew. The Soviet supply shock was far smaller in those occupations that require Hebrew fluency.

Suppose further that the wage elasticity $\eta$ is indeed negative, so that when a new wave of Soviet émigrés arrives in Israel, the average wage in the occupations where Hebrew fluency is unimportant falls. The OLS wage elasticity reported in Table 6 is 
essentially measuring the wage change in the occupations where Hebrew fluency is irrelevant (i.e., the occupations actually affected by the supply shock) relative to the wage change in occupations where Hebrew fluency is required (i.e., the occupations less affected by the supply shock). Our IV estimate is picking up exactly the same effect. The first-stage, which uses an instrument on the occupations where prior Soviet waves were actually employed in Israel, will predict that few of the émigrés enter occupations with strict Hebrew fluency requirements. As a result, the OLS and IV specifications would lead to almost identical estimates of the wage elasticity.

Friedberg's (2001) instrument, the occupation where the émigré was employed in the Soviet Union, ignores that skills are not perfectly transferable across countries and that the émigrés may only be able to enter certain occupations in Israel. This implies that the first-stage regression will allocate a worker who used to be a TV personality into a similar occupation in Israel, an occupation that may require near-perfect Hebrew fluency and that, in fact, employs very few such émigrés. As a result, the Friedberg IV wage elasticity may be comparing wages before and after the shock in occupations that have strict Hebrew fluency requirements (i.e., an occupation where there was little supply increase) with wage changes in jobs where Hebrew fluency is unimportant (i.e., occupations where the supply increase was much larger). This would result in a positive estimate of the wage elasticity. In short, Friedberg's IV is effectively giving more weight to occupations that, in fact, did not receive a shock.

To document the importance of skill downgrading when measuring wage impacts in the Israeli context, we carried out two distinct exercises. First, for each education level we can distribute the émigrés according to the native distribution across occupations in 1983. This prevents the across-occupation skill downgrading and plays a role similar to the instrument used in Friedberg's study. Alternatively, we can keep the distribution of émigrés across occupations as observed in the data, allowing émigrés to enter occupations normally performed by lower educated workers, but within each of those occupations we can then assume that the émigré inflow was distributed into the different education groups according to the native distribution of education, where natives tended to be less educated. This allows for skill downgrading along both the occupation and education dimensions. 
Table 8 reports the regression results from both exercises. When using the distribution of natives across occupations to assign the Soviet émigrés, we obtain an estimate of the wage elasticity equal to 0.257 (0.683), which resembles the Friedberg (2001, Table II) IV estimate of 0.549 (1.28). If, instead, we keep the occupation distribution of migrants as observed, but assign them to different education levels following the native distribution within each occupation, we obtain an estimate of -0.72 . Note that this own wage elasticity is virtually identical to the OLS and IV estimates reported in Tables 6 and 7.

In sum, the evidence strongly indicates that Soviet émigrés landed in occupations that were quite different from the occupations they held in the former Soviet Union, leading them to compete with natives in the occupations they actually entered rather than in the occupations they held before migration. Moreover, it is also possible that there was some skill downgrading even within occupations, with some highly educated migrants performing tasks normally done by middle-skill Israelis.

Put differently, skill downgrading occurred along the two dimensions that we use to define the various cells, and ignoring the fact that measured skills may not be highly correlated with marketable skills can lead to a substantial attenuation of the wage impact of immigration.

\section{The Algerian War of Independence}

The Algerian War ended with the signing of the Evian Accords on March 19, 1962. Although France "insisted that the settler citizens stay and become a part of the Algerian nation" (Choi, 2016, pp. 2, 4), the so-called settler citizens and other Algerians had other ideas, and Algerian independence quickly sparked a flow of refugees to France. In the summer of 1962 alone, "750,000 French citizens including 100,000 naturalized Jews and several thousand pro-French Muslim Algerians fled the nationalist takeover." Over time, the number of refugees increased, as the pre-independence population of Algeria included "900,000 white colonials of mixed European descent known otherwise as pieds noirs."

As this very brief summary of the events that followed the Evian Accords suggests, the independence of Algeria sparked two distinct types of refugee flows into France. The first consisted of the French repatriates, the French nationals (or "settler citizens") who 
lived in Algeria and returned to France after 1962. The second consisted of Algerian nationals. In fact, the number of Algerian nationals moving to France increased sharply in 1964 "with the arrival of over 75,000 harkis, the Muslim Algerian soldiers who had fought on the French side during the War of Independence" (Choi, 2016, p. 6).

Hunt (1992) examined the labor market impact of the first of these refugee flows, consisting of repatriates, on the French labor market. Her analysis suggests that the repatriates had only a small (but adverse) impact on the unemployment rate or wage of French native workers.

As was common in the early studies that examined refugee supply shocks, however, Hunt's regression analysis ignored that the supply shock of repatriates may have been particularly large in some skill groups, and much less important in other groups. In particular, her regression analysis consisted of essentially correlating the change in a measure of (age- and education-adjusted) labor market outcomes in a particular city on a measure of the total supply shock of repatriates affecting that city. As we have repeatedly emphasized, it is crucial to carefully match the skill level of French natives with the skill level of the refugees to correctly measure the labor market impact of the supply shock.

In addition, the Hunt study overlooked the fact that the end of the Algerian war ignited a sizable and concurrent flow of Algerian nationals. It is unlikely that the two refugee flows are uncorrelated. If nothing else, the timing of both flows was motivated by the same political upheaval.

Our examination of the refugee supply shocks sparked by the end of the Algerian conflict shows that the skill composition of the two groups of refugees and their geographic clustering in France differ not only from each other, but also from that of the French native workforce. A more careful identification of the French workers who might have been most affected by either supply shock suggests that the end of the Algerian War did indeed have adverse and sizable repercussions on competing workers in the French labor market.

\subsection{Summary statistics}


We use the 1962 and 1968 French census microdata maintained at IPUMS to determine the size and skill composition of the two refugee shocks originating in Algeria. ${ }^{33}$ Each census enables us to count and document the characteristics of persons who were not living in France at the time of the earlier census, which occurs six years prior to the enumeration.

Table 9 reports the counts of persons in three key demographic groups: the number of French repatriates (or French nationals who were not living in France at the time of the last census); the number of Algerian refugees (or Algerian nationals who were not living in France at the time of the last census); and the number of French natives (or French nationals who were living in France at the time of the last census).

The 1968 French census enumerated 1.4 million persons of French nationality who were not living in France in 1962. Although the census data maintained at IPUMS do not indicate where these persons resided in 1962, the historical context suggests that a sizable fraction of this group originated in Algeria. ${ }^{34}$ The supply shock of repatriates increased the size of the native French population by about 3 percent.

In addition, 162,000 Algerian nationals migrated to France between 1962 and 1968, so that this supply shock increased the size of the population by about 0.4 percent. Note, however, that nearly 23 percent of French repatriates and almost half of the Algerian nationals were men in their prime work years, compared to only 20 percent of French natives 35

Our empirical analysis of the impact of the two supply shocks focuses on the group of native French men aged 25-59, a group that had 9.1 million oersons in 1968. The

33 It is important to note that the 1962 census enumeration was carried out before the bulk of refugees arrived in France after the Evian accords were signed in late March 1962. In other words, it is unlikely that the labor supply decisions of French natives enumerated in the 1962 census were affected by the influx of refugees who would soon enter the country.

${ }^{34}$ We experimented with alternative definitions of the repatriate population, such as including French nationals who had moved to France prior to 1962. The analysis reported below opts for the most conservative definition in the sense that it leads to relatively weak labor market impacts of the repatriates. It is important to note that, concurrent with the repatriate and Algerian supply shocks, there was also a lot of churn in the number of foreign-born persons in France due to the entry and exit of over a million guest workers, mainly from Spain, Portugal, and Italy.

35 Table 9 also suggests that the bulk of the Algerian refugee influx was disproportionately male: 88 percent of the refugees aged 25-59 were men. The respective statistic for the entire population of Algerian refugees was 78 percent. 
repatriates increased the size of this population by 3.3 percent, while the Algerian refugees increased its size by almost 1 percent.

Table 9 also documents the remarkable difference in the skill composition of the various groups. Practically all (96 percent) of the Algerian refugees had less than a primary education, as compared to only 37 percent of the French natives and 26 percent of the repatriates. The extreme concentration of the Algerian refugees in the least skilled category implies that this specific supply shock increased the number of low-skill workers in the aggregate French labor market by 2.2 percent.

In contrast, the skill composition of the French repatriates was much more balanced, and comparable to that of French natives, with a slight skew towards a more skilled composition. Among men aged 25-59, for example, 26 percent of French natives and 37 percent of French repatriates had at least a secondary education.

The two refugee flows also differed in their geographic settlement after they arrived in France. The geographic sorting of the French repatriates very much resembled that of French natives, except that the region Provence-Alpes-Cote d'Azur received a somewhat larger share. However, a much larger number of the Algerian refugees settled in the Paris and southern regions. For example, 16 percent of Algerians settled in Rhone-Alpes, a region that hosted only 9 percent of French natives, and an additional 35 percent settled in Ile de France, but only 19 percent of French natives lived in the Paris metropolitan area.

We again exploit variation across region-education cells to estimate the labor market impact of the two distinct refugee supply shocks. The available French census data enables us to define 88 such cells ( 22 regions and 4 education groups). The extreme bunching of the Algerian refugees, both in terms of their educational attainment and their geographic distribution, into a relatively small number of cells creates a great deal of dispersion in the size of the supply shock across labor markets. This variation helps to more precisely identify the labor market impact of the Algerian nationals. In contrast, the similarity in the skills and (to some extent) geographic sorting of the French nationals and 
the French repatriates suggests that there may not be sufficient variation to precisely identify the impact of this particular supply shock. ${ }^{36}$

The bottom panel of Table 9 hints at the nature of the evidence. The ProvenceAlpes-Cote d'Azur region, where a large number of the very low-skilled Algerian nationals eventually settled, witnessed an increase in the unemployment rate of French natives with less than a primary education of 2 percentage points (double the national average), and a decrease in the employment rate of 3 percentage points (in contrast to an increase in the employment rate for this skill group of 1 percentage point in the national labor market).

\subsection{Results}

Table 10 reports the regression coefficients obtained from alternative specifications of the generic regression model that identifies the own effect of supply shocks in equations (5) and (7). Because there are two distinct, though concurrent, supply shocks, the regression specification is expanded to include the measure of the supply shock for each of the two types of refugees.

The French census data do not report any information on a worker's earnings, so that we use two alternative variables to measure the labor market impact of the refugees: the unemployment rate (defined as the fraction of the labor force participants in a particular cell who are unemployed); and the employment rate (defined as the fraction of the population in the cell that is employed). The dependent variables used in the regressions give the change in each of these employment indicators for each regioneducation cell between 1962 and 1968.

The OLS coefficients are reported in the first two columns of the bottom two panels of the table. It is evident that the flow of Algerian refugees had a sizable and statistically significant positive effect on the unemployment rate of French natives, as well as a negative, significant, and quantitatively larger effect on their employment rate, in line with what the summary evidence reported in the bottom panel of Table 9 suggested. In other words, the supply shock of Algerian refugees drove competing French natives out of the labor market,

\footnotetext{
36 This fact explains why we do not include location fixed effects in the regressions reported in Table 10. Including these fixed effects does not change the results for the Algerian inflows, but makes the coefficients for the French repatriates supply shock very unstable.
} 
and made the job-finding process more difficult for those natives who stayed in the market. Because the Algerian refugee flow was disproportionately composed of workers with very low skills and clustered in a small number of locations, the regressions are essentially indicating that very low-educated native workers in a small number of French cities were indeed adversely affected by the Algerian supply shock.

It is easy to see the positive impact of the Algerian supply shock on the unemployment rate of comparable French natives in the raw data. The bottom panel of Figure 4 shows the scatter diagram illustrating the relation between the change in the unemployment rate in a particular region-education cell and the size of the corresponding Algerian supply shock. It is obvious that the unemployment rate increased most for French workers in those region-education cells most affected by the entry of the Algerian refugees.

Moreover, the effect of this supply shock on the unemployment rate is numerically large. A 5 percent increase in the size of the cell due to an influx of Algerian refugees, which is roughly the size of the shock in the most affected region-education cell (natives who did not complete their primary education living in Provence-Alpes-Cote d'Azur) increased the unemployment rate of this group by 1.3 percentage points. The French unemployment rate for prime-age, low-skill men in the mid-1960s was only 2 percent, so that the supply shock had a substantial impact on French unemployment.

In contrast, we find that although the impact of the repatriates on the employment and unemployment rates of French natives generally has the "right" sign in the OLS regressions, the coefficient is always insignificant. The weak effect becomes statistically significant only in the unemployment rate regressions after we account for the endogeneity of the geographic distribution of the repatriates. The first-stage coefficients reported in the top panel of Table 10 show that both the geographic sorting of the Algerian refugees and the French repatriates was strongly correlated to where previous Algerian refugees and repatriates settled. ${ }^{37}$ Assuming that the lagged geographic sorting is a valid instrument, the

\footnotetext{
37 It is important to note that the flow of repatriates, unlike the flow of Algerian nationals, began prior to the end of the war in 1962. Many French nationals are recorded to have returned to France as early as 1954. The French census data available at IPUMS does not enable us to determine the origin of these repatriates. However, their skill and location distribution is similar to the larger flow of repatriates that followed the conclusion of the Algerian independence war.
} 
IV regressions in the bottom two panels show that both the repatriates and the Algerian refugees had a significant impact on the unemployment rates of French natives.

Finally, the fact that the supply shock of French repatriates was "balanced" across the education cells makes it difficult to estimate the resulting cross-effects using the regression framework derived earlier. We simplified the estimation of cross-effects by explicitly relying on the fact that refugee supply shocks are often very unbalanced in their skill composition, so that we need only look at how the labor market outcomes of different skill groups relate to the supply shock experienced by the one skill group that was most affected. We can obviously carry out this exercise to estimate the cross effects resulting from the supply shock of Algerian nationals, but it is not possible to use the methodology to estimate the corresponding cross effects from the supply shock of French repatriates.

As Table 9 shows, the supply shock of Algerian nationals was extremely unbalanced. Almost all the Algerians who arrived to France between 1962 and 1968 had not completed their primary education, suggesting that we can use equation (12) to determine how the low-skill Algerians affected the employment opportunities of more skilled French natives.

Table 11 reports selected coefficients from the cross-effects regressions. Not surprisingly, the regressions still report an adverse own effect-employment rates are lower and unemployment rates are higher for French natives who do not have a primary education. However, we cannot detect any evidence of beneficial cross-effects in this episode. The unemployment rate of more skilled natives did not fall when very low-skill Algerian nationals entered their specific labor market. Moreover, the evidence indicates that the employment rate of skilled French natives also fell, although it fell by significantly less than the drop experienced by low-skill workers. We have been unable to determine the reason for the absence of beneficial complementarities in the Algerian context. One obvious conjecture is that the supply shock of Algerian nationals was quite unique in terms of just how low-skill the refugees were relative to the baseline population.

\section{The Balkan refugees}

For many of the people living in Europe during the 1990s, the names of Srebrenica, Sarajevo, Pristina, and Podgorica are indelibly associated with incidents from the last set of 
wars fought on European soil. After the collapse of communism, the former republic of Yugoslavia split into five new countries between 1991 and 1992: Slovenia, Croatia, BosniaHerzegovina, Serbia, and Macedonia. This breakup, however, was not without conflict. Various episodes of civil and military unrest hit the former communist country between 1990 and 2000. There were many casualties, and many more people lost their homes and sought refuge by moving elsewhere, either internally within the territory of the former Yugoslavia or to other countries in Europe.

It is difficult to estimate precisely how many of the Balkan refugees created by the continuous conflict moved to European countries. The different timing and location of the various wars, as well the persistence of the fighting, generated distinct waves of refugees. For example, the first wars started in northern Yugoslavia, when Slovenia and Croatia in 1991, and then Bosnia in 1992, declared independence. The war in Croatia and Bosnia lasted until 1995 when the Federal Republic of Yugoslavia recognized Croatia and BosniaHerzegovina as independent countries. In 1996, ethnic Albanians in Kosovo formed the Kosovo Liberation Army to fight for the creation of an ethnically separate Greater Albania. The War in Kosovo in 1998 and 1999 involved the southern region of former Yugoslavia, and affected large numbers of families. The calculation of the number of refugees created by this seemingly endless series of distinct conflicts is further complicated by the fact that many of the refugees eventually returned to parts of the former Yugoslavia once the wars ended.

The refugees from the former Yugoslavia tended to move to particular countries in Europe. The refugees then settled in particular regions within those countries. We rely on the variation across regions within different European countries to identify the labor market impact of this specific refugee supply shock.

\subsection{Summary Statistics}

We use census data for seven European destination countries: Austria, Greece, Ireland, Portugal, Romania, Spain, and Switzerland. These countries were chosen based on the following criteria. First, we only use European countries with publicly available census data in the IPUMS archive. Second, we only use countries where we can construct a "before" and "after" snapshot of the relevant national labor markets. The timing of the 
Yugoslav Wars suggests that the countries must have conducted a census around 1990 and another census around $2000 .^{38}$ Third, we need to enumerate and determine the skill distribution of the Balkan refugees, as well as measure their impact on the labor market opportunities of comparable natives. In other words, both the "pre" and "post" censuses for each country must report information on country of origin and labor market outcomes, and must report educational attainment in a manner that is comparable across countries.

Although other countries were recipients of large numbers of Balkan refugees at the time, the census data publicly available for those other countries do not satisfy our criteria. The French census, for example, does not report the country of origin of foreign-born persons. Similarly, the coding of educational attainment for the UK censuses differs significantly from that used by other countries. Finally, the relevant data are not available for either Germany or Sweden.

Table 12 shows that almost 260,000 persons born in the former Yugoslavia moved to the seven European countries in our analysis during the 1990s. ${ }^{39}$ This represents a very modest increase of only 0.3 percent in the aggregate population of those countries. However, as with many refugee supply shocks, the refugees clustered in a relatively small number of places. Almost all of the Balkan refugees settled in two of the countries included in our analysis, Austria and Switzerland, with Austria receiving 76 percent of the refugees and Switzerland receiving 17 percent. And, within those two countries, the refugees were further clustered in specific regions, providing sufficient variation for the identification of their labor market impact. For example, Vienna received 34 percent of the refugees in Austria, but only 19 percent of the native population resided in that city.

We again examine the labor market outcomes of the native-born population of men aged 25-59 in the various receiving countries. Table 12 reports that the Balkan refugees were disproportionately of intermediate skills. While 44 percent of prime-age men in the

38 Specifically, we use the 1991 and 2001 censuses in our analysis of Austria, Greece, Portugal, and Spain; the 1991 and 2002 censuses for Ireland; the 1992 and 2002 censuses for Romania; and the 1990 and 2000 censuses for Switzerland.

39 We obtain this number by comparing the stock of migrants from Yugoslavia circa 1990 to the stock of migrants from the former Yugoslavia circa 2000. 
receiving countries had completed a secondary education, 67 percent of the Balkan refugees had done so.

Our analysis of the Balkan refugees episode again defines a labor market as a particular region-education cell, where the region index now identifies a particular region within a particular country of destination. The publicly available census data allows us to identify 65 such geographic areas (across 7 different countries) in three different education groups, so that our analysis exploits variation across 195 cells.

Although our analysis complements Angrist and Kugler's (2003) initial examination of this specific refugee supply shock, there are several key differences between their study and ours. For example, Angrist and Kugler used annual data reporting labor market outcomes and migrant flows in all European countries. ${ }^{40}$ These annual data, however, do not provide any information on the educational attainment of the Balkan refugees or on the specific local labor markets (in a receiving country) that were affected by the supply shocks. Exploiting annual variation on labor market outcomes and on the size of supply shocks enables Angrist and Kugler to more precisely measure the changes in employment observed around the years of the Bosnian and Kosovo Wars. But the lack of information on educational attainment and the specific within-country regions most affected by the refugees implies that they must rely on aggregate differences across countries to identify the labor market impact. In a sense, our approach generates a greater degree of dispersion across markets that can help identification. At the same time, however, our approach limits the number of countries that can be used in such an analysis.

Figure 5 illustrates that within our set of 7 countries, it is mainly some regions in Austria and Switzerland that witnessed significant supply shocks of refugees from the former Yugoslavia. In fact, there are some regions in Austria where the influx of Balkan refugees increased the size of the workforce by about 5 percent in some education groups, while in (some very small cells in) Switzerland the size of the supply shock sometimes neared 20 percent.

40 The Angrist-Kugler annual data are drawn from the Labor Force Survey maintained by the Eurostat. 


\subsection{Results}

Table 13 reports coefficients obtained from the generic "own effects" regression models derived in equations (5) and (7). The pooled censuses from the seven European countries do not contain any information on a worker's earnings, so that our dependent variables are: the change in the unemployment rate (defined as the fraction of the labor force participants in a region-education cell who are unemployed); and the change in the native employment rate (defined as the fraction of the population in the cell that is employed). Note that all regression specifications reported in the table include country-ofdestination fixed effects, so that the impact of the supply shock is being identified from the variation across region-education cells within a particular country. ${ }^{41}$

The OLS coefficients of the "own" labor market impact are reported in the first two columns of the bottom two panels of the table. ${ }^{42}$ It is evident that the Balkan refugees had a positive and significant effect on the native unemployment rate and a negative (but insignificant) effect on the native employment rate. The point estimate suggests that a 5 percent refugee supply shock increases the unemployment rate of competing natives by about 1 percentage point. Because this particular supply shock was largest in Austria and Switzerland, where the unemployment rates in 2000 were 5.5 and 2.0 percent, respectively, the Balkan refugees had a sizable effect on native labor market opportunities in those two countries.

Figure 5 illustrates the raw data that generates this positive correlation between the supply shock and the change in the unemployment rate. It is evident that the positive unemployment effect is generated by the within-country variation in the size of the supply shock.

Of course, the Balkan refugees may be endogenously choosing which particular labor market to move to (in terms of choosing both a particular country of destination and a particular region within that country), obviously preferring to settle in locations that offer the best employment opportunities. To address the endogeneity concern, we again

\footnotetext{
${ }^{41}$ It is important to control for country fixed effects because different countries were trying to converge in macroeconomic conditions prior to entering the common currency union.

42 The regression results are similar if we estimate the regressions using only regional-education variation in the two countries (Austria and Switzerland) that received most of the Balkan refugees.
} 
use the migration network instrument. The question, of course, is whether the past share of workers from the former Yugoslavia (prior to its breakup) is a good predictor of where the new (post-breakup) migrants moved.

Our instrumental variables regression again exploits the variation across regions within each country. Interestingly, some regions in (mainly) Austria and Switzerland had larger shares of migrants from the former Yugoslavia prior to 1990 and also received many more migrants during the 1990s. The first two columns of the top panel of Table 13 reports the first stage coefficient, which is positive and significant, and suggests that a 10 percent higher share of migrants in a particular region prior to 1990 resulted in a 1.4 percent increase in the inflow rate during the 1990s-relative to other regions in the same country.

The use of IV to control for the geographic sorting of the Balkan refugees does not fundamentally alter our results, but the IV coefficients of the labor market impact are more imprecisely estimated. It is worth noting that our estimates of the "own" employment effects seem weaker than those estimated by Angrist and Kugler (2003) using crosscountry variation. For instance, Angrist and Kugler (2003, pp. F318, F322) report that 100 more migrants lead to 35 or 83 fewer native jobs (depending on whether the impact is estimated using OLS or IV, respectively). ${ }^{43}$

As we noted earlier, the Balkan refugees were disproportionately located in the middle of the education distribution; 67 percent of the refugees had a completed secondary education, as compared to 44 percent of natives. We use the cross-effects regression model derived in equation (12) to separately examine how this particular supply shock affected the employment outcomes of native persons at the two extremes of the skill distribution.

Table 14 summarizes the evidence on cross effects. Note that the expanded regression model in equation (12) still yields the finding of adverse own effects. In other words, there was an increase in the unemployment rate of native workers with a secondary education and a decrease in their employment rate. Equally important, the influx of a disproportionately large number of intermediate-skill refugees lowered the unemployment

\footnotetext{
43 The Angrist-Kugler point estimates assume a baseline immigration level of 5 percent. In contrast, using a setting similar to ours, Glitz (2012) examines variation across German regions that were differentially affected by the inflow of Soviet migrants after the collapse of the Soviet Union, and obtains employment effects that are quantitatively similar to those reported in Table 13.
} 
rate and increased the employment rate of low-skill natives who had at most a primary education. Although the beneficial cross-effects on low-skill natives are often not statistically significant, the point estimates consistently suggest that their employment outcomes improved because of the entry of so many refugees in the next higher rung of the skill distribution. However, the evidence on the presence of beneficial cross-effects for the most skilled European natives, those who had completed a university education, is far weaker.

\section{Summary}

The recent (and continuing) entry of hundreds of thousands of refugees into many European countries has already generated a great deal of political controversy and raised many questions that require a fuller understanding of the determinants and consequences of refugee supply shocks. This paper revisited some of the historical refugee flows to document the labor market consequences of refugee-induced increases in labor supply.

Specifically, our analysis reexamines the evidence surrounding four episodes: (1) The influx of the Marielitos into Miami in 1980; (2) the influx of French repatriates and Algerian nationals into France at the end of the Algerian War of Independence in 1962; (3) the influx of Jewish émigrés into Israel after the collapse of the Soviet Union in the early 1990s; and (4) the influx of refugees from the former Yugoslavia into some European countries during the long series of Balkan wars between 1991 and 2001.

Although the labor market consequences of each of these shocks have been separately examined in prior studies, our examination of the evidence differs from the prior literature in three key ways. First, we use a common empirical approach, based on the implications of factor demand theory, to document the labor market consequences of each of the refugee supply shocks. Despite the obvious differences in the historical, economic, and political forces that motivated the various refugee flows, the use of the same empirical framework to study each of the episodes reveals a common thread in the evidence:

Exogenous supply shocks adversely affect the labor market opportunities of competing natives in the destination countries. 
In some contexts, of course, this result implies that a refugee supply shock will mainly harm low-skill workers in some regions of the receiving country (as was the case with the influx of Marielitos into Miami or the influx of Algerian nationals into France). In other cases, however, it is the high-skill workforce in the receiving country that bears the brunt of the impact (as was the case with high-skill Israelis competing with large numbers of high-skill Soviet émigrés).

Second, the very different skill distributions of natives and refugees in some of these episodes suggests that these natural experiments can be further exploited to identify the impact of the supply shocks on potentially complementary native groups. For example, the low-skill Marielitos may have increased the wage or employment opportunities of high-skill Miamians, while the high-skill Soviet émigrés may have benefited low-skill Israelis. These complementarities should obviously be an important part of any assessment of how refugee supply shocks alter the employment opportunities of native workers. Our empirical analysis documents that, in many cases, these beneficial effects do indeed exist and are numerically important.

Finally, rather than rely on proprietary or confidential data, we only use the publicly available census microdata maintained at IPUMS. Our use of easily accessible data to examine the impact of refugee supply shocks implies that our results are fully reproducible. The reproducibility of the evidence in this context is essential because the recent refugee supply shocks in Europe have already sparked extremely contentious policy debates in many receiving countries.

Our empirical analysis of the four historical episodes of refugee supply shocks teaches an important lesson. Although these episodes differ in countless ways, a universal theme seems to connect the evidence. Put bluntly, the humanitarian principles that encourage receiving countries to accept as many migrants as possible have important distributional consequences, as predicted by the canonical model of supply and demand in the labor market. 


\section{Appendix: Skill Downgrading as an Omitted Variable}

A simple way to think about skill downgrading is to assume that an exogenous (and constant) fraction $\pi$ of the high-skill refugees actually enter the low-skill market. Equations (10a) and (10b) show that the change in labor market outcomes for the two skill groups $h$ and $u$ are determined by:

$$
\begin{aligned}
& \Delta \log w_{r h}=\theta-\eta \frac{M_{r h}}{L_{r h 1}}-\eta \pi \frac{-M_{r h}}{L_{r h 1}}+e_{r h}, \\
& \Delta \log w_{r u}=\theta-\eta \frac{M_{r u}}{L_{r u 1}}-\eta \pi \frac{M_{r h}}{L_{r u 1}}+e_{r u} .
\end{aligned}
$$

This implies that the estimating equation can be written as:

$$
Y_{r}=\alpha+\beta X_{r}+\gamma Z_{r}+\varepsilon_{r},
$$

where the vector $Y_{r}=\left(\Delta \log w_{r h}, \Delta \log w_{r u}\right)$ and,

$$
\begin{aligned}
& X_{r}=\left(x_{r h}, x_{r u}\right)=\left(\frac{M_{r h}}{L_{h 1}}, \frac{M_{r u}}{L_{r u 1}}\right), \\
& Z_{r}=\left(z_{r h}, z_{r u}\right)=\left(\frac{-M_{r h}}{L_{r h 1}}, \frac{M_{r h}}{L_{r u 1}}\right) .
\end{aligned}
$$

Without loss of generality, we can measure variables as deviations from their means. If we estimate equation (A1) using OLS, but excluding $Z$, we have a standard problem of omitted variable bias. The bias depends on the covariance between $X$ and $Z$ :

$$
\operatorname{plim} \hat{\beta}=\beta+\gamma \operatorname{plim} \frac{\sum_{r, j} x_{r j} z_{r j}}{\sum_{r, j} x_{r j}^{2}} .
$$

We can further simplify:

$$
\operatorname{Bias}=\gamma \operatorname{plim} \frac{\sum_{r, j} x_{r j} z_{r j}}{\sum_{r, j} x_{r j}^{2}}=\gamma \operatorname{plim} \frac{\sum_{r} x_{r l} z_{r h}+\sum_{r} x_{r u} z_{r u}}{\sum_{r} x_{r h}^{2}+\sum_{r} x_{r u}^{2}} .
$$

Define $\sigma_{h}^{2}=\operatorname{Var}\left(M_{r h} / L_{r h 1}\right) ; \sigma_{u}^{2}=\operatorname{Var}\left(M_{r u} / L_{r u 1}\right) ;$ and $\sigma_{h u}=\operatorname{Cov}\left(M_{r h} / L_{r h 1}, M_{r u} / L_{r u 1}\right)$. The variances $\left(\sigma_{h}^{2}, \sigma_{u}^{2}\right)$ measure the dispersion in high-skill and low-skill refugee supply 
shocks across markets $r$, and the covariance $\sigma_{h u}$ measures the relation between high-skill supply shocks and low-skill supply shocks. It then follows that:

$$
\begin{aligned}
& \operatorname{plim}\left(\sum_{r} x_{r h} z_{r h}\right)=\operatorname{plim}\left(\sum_{r} \frac{M_{r h}\left(-M_{r h}\right)}{L_{r h 1} L_{r h 1}}\right)=-\sigma_{h}^{2}, \\
& \operatorname{plim}\left(\sum_{r} x_{r u} z_{r u}\right)=\operatorname{plim}\left(\sum_{r} \frac{M_{r u} M_{r h}}{L_{r u 1} L_{r u 1}}\right)=\operatorname{plim}\left(\sum_{r} \frac{M_{r u}}{L_{r u 1}} \frac{M_{r h}}{L_{r h 1}} \frac{L_{r h 1}}{L_{r u 1}}\right)=\sigma_{h u} R,
\end{aligned}
$$

where $R=\operatorname{plim}\left(L_{r h 1} / L_{r u 1}\right)$. For simplicity, we consider the case where "skills" are defined so that the skill distribution of the native workforce is "balanced," and $R=1$. It also follows that:

$$
\operatorname{plim}\left(\sum_{r} x_{r h}^{2}+\sum_{r} x_{r u}^{2}\right)=\operatorname{plim}\left(\sum_{r}\left(\frac{M_{r h}}{L_{r h 1}}\right)^{2}+\sum_{r}\left(\frac{M_{r u}}{L_{r u 1}}\right)^{2}\right)=\sigma_{h}^{2}+\sigma_{u}^{2} .
$$

The correlation between high- and low-skill supply shocks across markets is given by $\rho_{h u}=\sigma_{h u} / \sigma_{h} \sigma_{u}$. Combining expressions yields equation (10) in the text:

$$
\operatorname{plim} \hat{\eta}=\eta-\eta \pi \frac{\sigma_{h}^{2}}{\sigma_{h}^{2}+\sigma_{u}^{2}}\left[1-\rho_{h u} \frac{\sigma_{u}}{\sigma_{h}}\right] .
$$




\section{References}

Abadie, A., A. Diamond, and J. Hainmueller (2010). "Synthetic control methods for comparative case studies: Estimating the effect of California's tobacco control program", Journal of the American Statistical Association, 105(490), 493-505.

Alexe, D. (2015). “Angela Merkel: No legal limit to refugee numbers,” World Affairs Journal, September 11.

Altonji, J., and D. Card (1991). "The effects of immigration on the labor market outcomes of less-skilled natives", in J. Abowd and R. Freeman (eds.), Immigration, Trade, and the Labor Market, pp. 201-234. University of Chicago Press, Chicago.

Angrist, J., and A. Kugler (2003). "Protective or counter-productive? European labor market institutions and the effect of immigrants on EU natives", Economic Journal 113(488), F302-F331.

Borjas, G. (1987). "Self-selection and the earnings of immigrants", American Economic Review 77(4), 531- 553.

-------. (2003). “The labor demand curve is downward sloping: Reexamining the impact of immigration on the labor market", Quarterly Journal of Economics 118(4), 13351374.

(2014). Immigration Economics, Harvard University Press, Cambridge, MA.

------. (2016). “The wage impact of the Marielitos: Additional evidence”, No. w21850, National Bureau of Economic Research.

-------. (2017). “The wage impact of the Marielitos: A reappraisal”, Industrial and Labor Relations Review, forthcoming.

Borjas, G., R. Freeman, and L. Katz. (1997). "How much do immigration and trade affect labor market outcomes?”, Brookings Papers on Economic Activity, 1-67.

Buwalda, P. (1997). They did not dwell alone: Jewish Emigration from the Soviet Union 1967-1990, Woodrow Wilson Center Press, Washington, DC.

Card, D. (1990). "The impact of the Mariel boatlift on the Miami labor market", Industrial and Labor Relations Review 43(2), 245-257.

------. (2001). "Immigrant inflows, native outflows and the local labor market impacts of higher immigration", Journal of Labor Economics 19(1), 22-64.

Card, D., and G. Peri. (2016). "Immigration Economics: A review”, working paper, University of California, Berkeley.

Choi, S.E. (2016). Decolonization and the French of Algeria: Bringing the settler colony home, Palgrave Macmillan, New York. 
Cohen-Goldner, S., and M. Paserman. (2011). "The dynamic impact of immigration on natives' labor market outcomes: Evidence from Israel," European Economic Review, 55(8), 1027-1104.

Dustmann, C., T. Frattini, and I. Preston. (2013). "The effect of immigration along the distribution of wages", Review of Economic Studies 80(1), 145-173.

Dustmann, C., U. Schonberg, and J. Stuhler. (2017). "Labor supply shocks and the dynamics of local wages and employment", Quarterly Journal of Economics, forthcoming.

Fernandez-Huertas, J. (2012). "New evidence on emigrant selection", Review of Economics and Statistics, 93(1): 72-96.

Friedberg, R. (2001). "The impact of mass migration on the Israeli labor market", Quarterly Journal of Economics, 116(4), 1373-1408.

Glitz, A. (2012). "The labor market impact of immigration: A quasi-experiment exploiting immigrant location rules in Germany", Journal of Labor Economics, 2012, 30(1), 175-213.

Grossman, J. (1982). "The substitutability of natives and immigrants in production", Review of Economics and Statistics 54(4), 596-603.

Hunt, J. (1992). "The impact of the 1962 repatriates from Algeria on the French labor market", Industrial and Labor Relations Review 45(3), 556-572.

Jaeger, D., J. Ruist, and J. Stuhler. (2016). "Are lagged immigrant shares valid as instruments?", working paper.

Monras, J. (2014). “Online appendix to 'Immigration and wage dynamics: evidence from the Mexican Peso crisis'”, Sciences Po.

-------. (2015a). “Immigration and wage dynamics: Evidence from the Mexican Peso crisis”, No. 8924, IZA Discussion Paper.

------. (2015b). “Economic shocks and internal migration”, No. 8840, IZA Discussion Paper.

Ottaviano, G. and G. Peri. (2007). "The effects of immigration on U.S. wages and rents: A general equilibrium approach", No. 13/07, Centre for Research and Analysis of Migration.

------. (2012). "Rethinking the effect of immigration on wages", Journal of the European Economic Association 10(1), 152-197.

Peri, G. and V. Yasenov. (2015). "The labor market effects of a refugee wave: Applying the synthetic control method to the Mariel boatlift", No. w21801, National Bureau of Economic Research. 


\section{Figure 1. The impact of the Mariel supply shock on native wages}

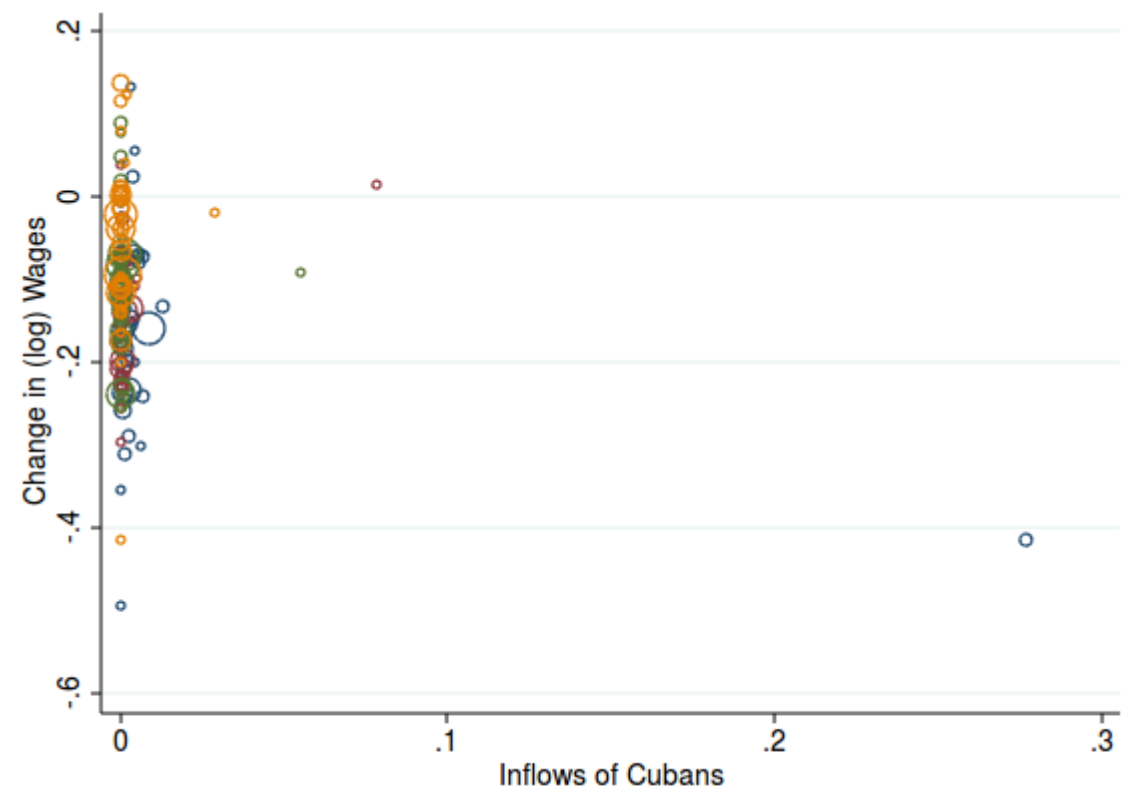

Notes: This figure plots the change in the wage of native men aged 25-59 against the size of the migrant inflow in each city-education cell using the March CPS survey years of 1978-1980 as the pre-migration period and the March CPS survey years of 1982-1985 as the post-migration period. Each dot represents a cityeducation cell. The size of the dots represents the size of the cells. Blue, red, green, and yellow dots indicate "less than primary", "Primary completed", "Secondary completed", and "University completed" respectively. The figure exploits variation across 38 metropolitan areas and 4 education groups. 


\section{Figure 2. The impact of the Soviet émigrés on native wages}

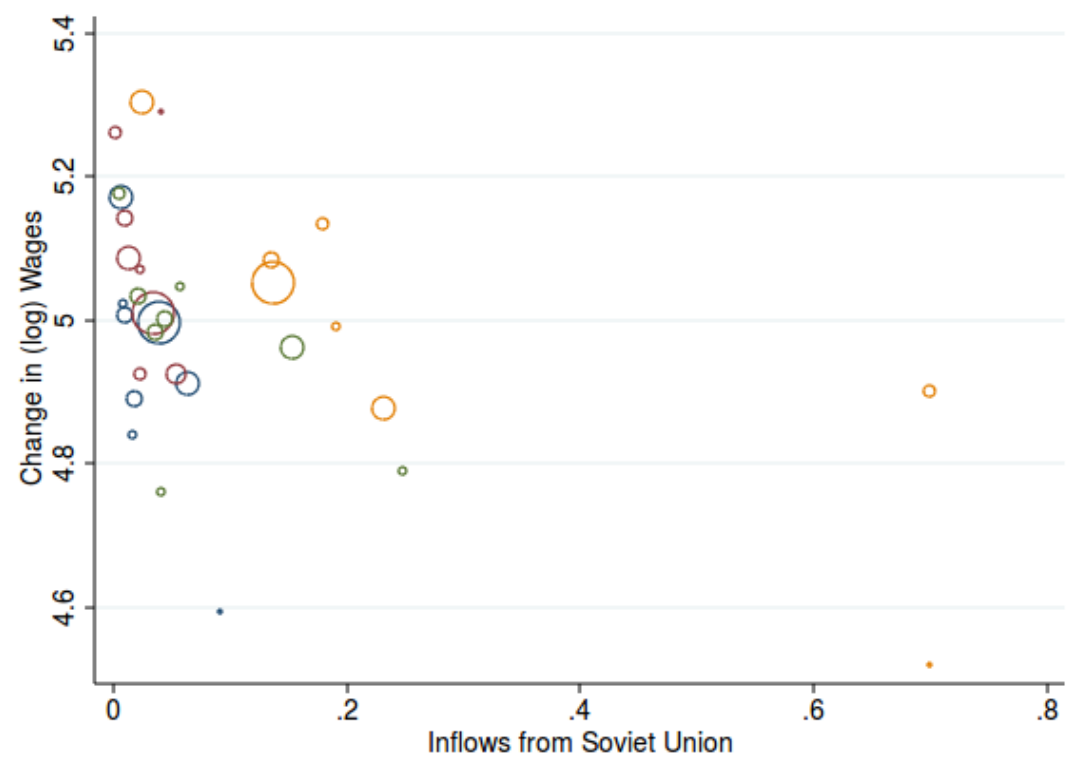

Notes: This figure plots the 1983-1995 change in the annual earnings of native Israeli men aged 25-59 against the size of the migrant inflow in each cell. Each dot represents an education - occupation cell. Blue, red, green, and yellow dots indicate "less than primary", "Primary completed", "Secondary completed", and "University completed" respectively. The size of the dots represents the size of the cells, measured by the optimal weights used in the regression tables. The figure exploits variation across 4 educations groups and 8 occupation categories. 


\section{Figure 3. Soviet inflows and language use prior to the supply shock}

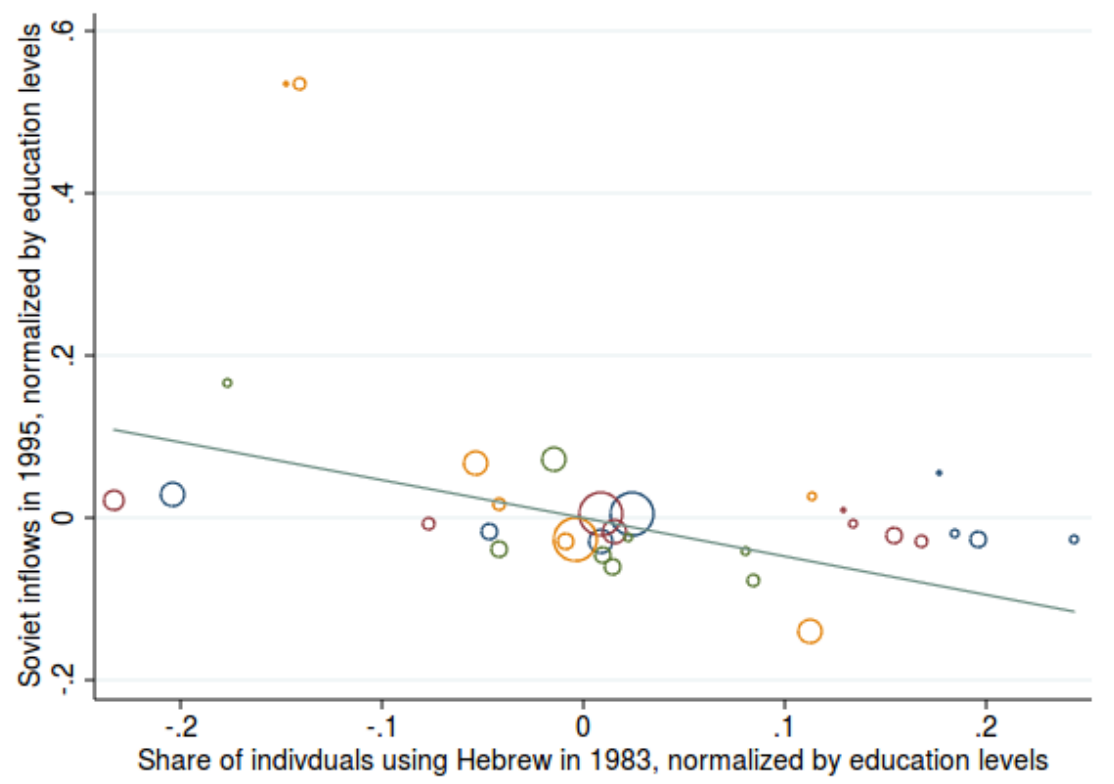

Notes: The figure plots the inflow of Soviet émigrés against the share of workers who speak Hebrew as their first language in 1983 and who were not from the Soviet Union. We remove education fixed effects from both variables. Each dot represents an education-occupation cell. Blue, red, green, and yellow dots indicate "less than primary", "Primary completed", "Secondary completed", and "University completed" respectively. The figure exploits variation across 4 educations groups and 8 occupation categories. 


\section{Figure 4. The impact of the supply shocks after the Algerian War on the native unemployment rate}

\section{A. The French repatriates}

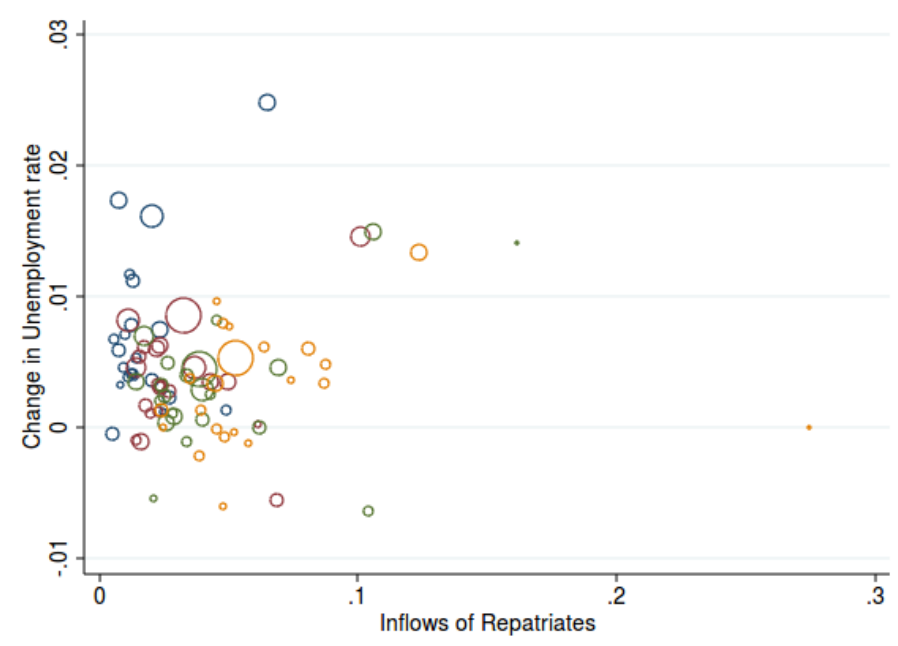

\section{B. The Algerian nationals}

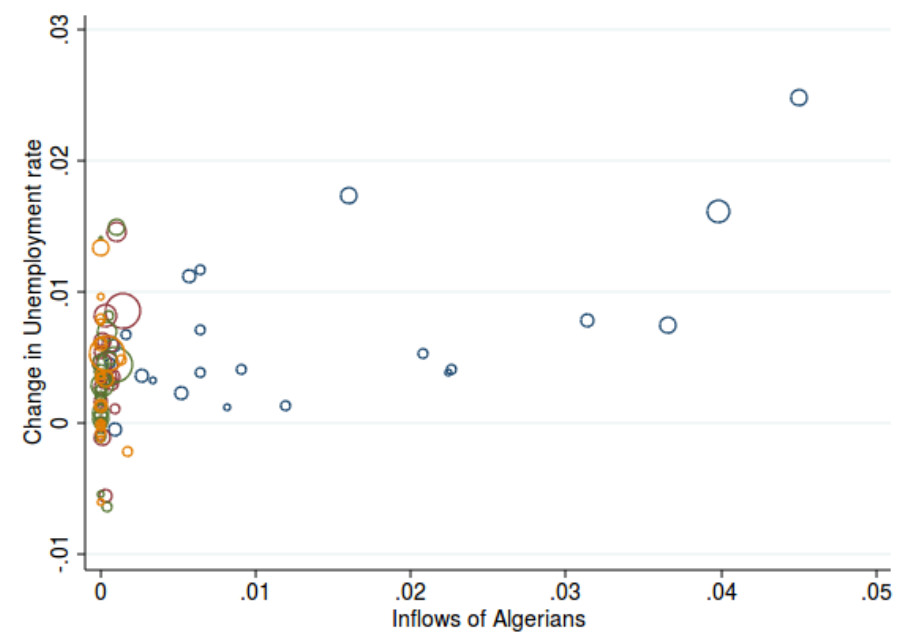

Notes: The figure plots the 1962-1968 change in the unemployment rate of French native men aged 25-59 against the size of the migrant inflow in each cell. Each dot represents a region-education cell. The top figure shows the impact of the French repatriates and the bottom figure shows the impact of the Algerian nationals. Blue, red, green, and yellow dots indicate "less than primary", "Primary completed", "Secondary completed", and "University completed" respectively. The size of the dots represents the size of the cells. The figure exploits variation across 4 education groups and 22 locations. 


\section{Figure 5. The impact of the Balkan refugees on the native unemployment rate}

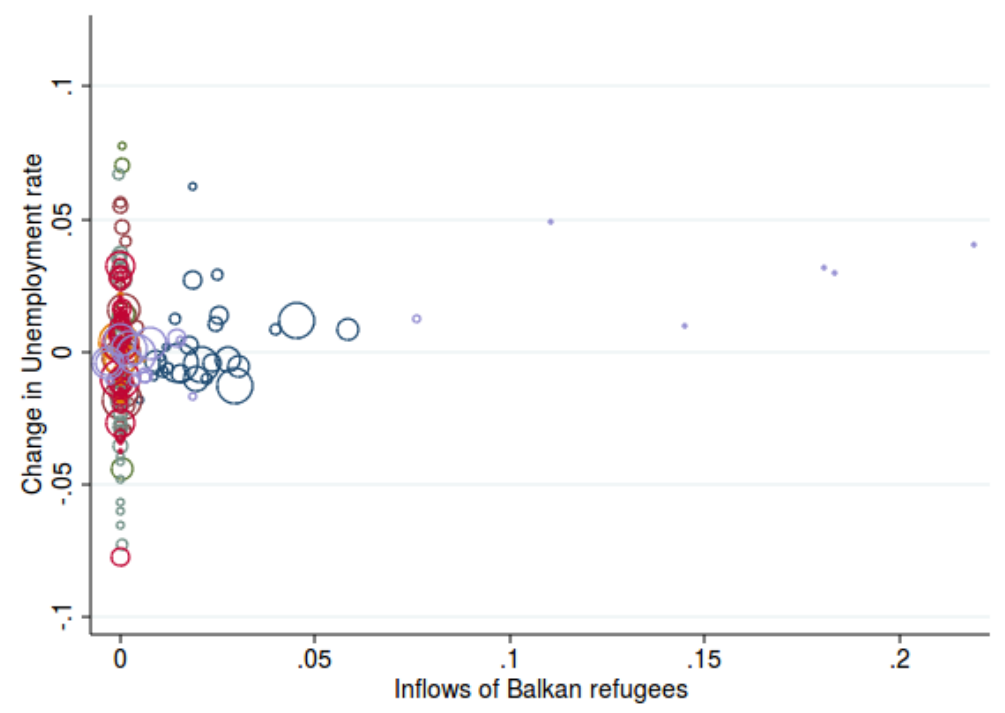

Notes: The figure plots the change in the unemployment rate of native men in 7 European countries against the size of the migrant inflow in each cell between the Census year closest to 1990 and the Census year closest to 2000 for each of the countries used. Each dot represents a country of destination-region within the country-education cell. Country fixed effects are removed in the graph. Different colors represent the different countries used: Austria, Greece, Ireland, Portugal, Romania, Spain, and Switzerland. The size of the dots represents the size of the cells. The figure exploits variation across 3 education groups and 65 locations. 


\section{Table 1. Overview of the four refugee supply shocks}

\begin{tabular}{|c|c|c|c|c|c|}
\hline \multirow[b]{2}{*}{ Refugee supply shock: } & \multicolumn{2}{|c|}{$\begin{array}{c}\text { Number of refugees } \\
\text { (in 1000s) }\end{array}$} & \multirow[b]{2}{*}{$\begin{array}{c}\text { Localities/occupations } \\
\text { most affected }\end{array}$} & \multirow[b]{2}{*}{$\begin{array}{c}\text { Predominant skills } \\
\text { of the refugees }\end{array}$} & \multirow[b]{2}{*}{$\begin{array}{l}\text { Increase in supply of } \\
\text { most affected group }\end{array}$} \\
\hline & All & $\begin{array}{c}\text { Men aged } \\
25-59 \\
\end{array}$ & & & \\
\hline 1. Mariel, 1980 & 120.6 & 47.9 & Miami & High school dropouts & $\begin{array}{l}\text { 31.9\% (male high school } \\
\text { dropouts in Miami) }\end{array}$ \\
\hline 2. Soviet émigrés to Israel, 1990 & 476.5 & 101.6 & $\begin{array}{l}\text { Skilled workers in } \\
\text { industry and } \\
\text { construction }\end{array}$ & College graduates & $\begin{array}{l}267.9 \% \text { (male college } \\
\text { graduates in "skilled } \\
\text { workers in industry and } \\
\text { construction") }\end{array}$ \\
\hline
\end{tabular}

3. The Algerian Independence War, 1962

A. French Repatriates

B. Algerian Nationals

4. The Yugoslav Wars, 1991-2001
1358.9

302.0

\section{Provence-Alpes-Cote} d'Azur

Provence-Alpes-Cote d'Azur

Some cities in Austria Secondary schooling and Switzerland

\section{Balanced across} groups
Less than primary schooling completed

10.2\% (men in ProvenceAlpes-Cote d'Azur)

$5.8 \%$ (men with less than primary schooling in Ile de France)

4.6\% (men in Vienna) 


\section{Table 2. Size and skill composition of the Mariel supply shock}

All persons (in 1000s)

Aged 25-59

Men, 25-59

$\%$ of men aged 25-59 with education:

High school dropouts

High school graduates

Some college

College graduates

Sample size, men 25-59

All persons (in 1000s)

Aged 25-59

Male, aged 25-59

$\%$ of men aged 25-59 with education:

High school dropouts

High school graduates

Some college

College graduates

Sample size, men 25-59

Outside Miami

High school dropouts

High school graduates

Some college

College graduates

Miami

High school dropouts

High school graduates

Some college

College graduates

\begin{tabular}{ccc}
\multicolumn{3}{c}{ Census data, 1990 } \\
\hline Marielitos & Natives & \% increase in supply \\
\hline 120.6 & 247339.0 & 0.05 \\
73.2 & 105674.6 & 0.1 \\
47.9 & 51696.4 & 0.1
\end{tabular}

$\begin{array}{lll}62.2 & 20.1 & 0.3\end{array}$

$\begin{array}{lll}17.3 & 27.7 & 0.1\end{array}$

$\begin{array}{lll}13.8 & 26.3 & 0.0\end{array}$

$\begin{array}{lll}6.6 & 25.9 & 0.0\end{array}$

$2211 \quad 2577549$

Census data 1990, Miami counts

\begin{tabular}{ccc}
\hline Marielitos & Natives & \% increase in supply \\
\hline 69.4 & 852.7 & 0.08 \\
54.7 & 576.0 & 0.09 \\
34.5 & 290.5 & 0.12
\end{tabular}

$\begin{array}{lll}62.4 & 23.2 & 31.9\end{array}$

$\begin{array}{lll}15.9 & 21.7 & 8.7\end{array}$

$\begin{array}{lll}14.5 & 27.5 & 6.3\end{array}$

$\begin{array}{lll}7.2 & 27.6 & 3.1\end{array}$

$833 \quad 6692$

March CPS data, pooled 1978-1984 surveys

Sample size $\Delta \log$ wage $\Delta$ unemployment rate

$\begin{array}{rrr}8718 & -0.17 & 0.06 \\ 20299 & -0.15 & 0.04 \\ 12431 & -0.12 & 0.03 \\ 19898 & -0.06 & 0.01\end{array}$

$\begin{array}{lll}146 & -0.41 & 0.04\end{array}$

$\begin{array}{lll}218 & 0.02 & 0.03\end{array}$

$\begin{array}{lll}2187 & -0.09 & -0.06\end{array}$

$\begin{array}{lll}192 & -0.02 & -0.03\end{array}$

Notes: The top two panels report data from the 1990 Census based on 1985 locations, with age levels referring to 1985 . The Marielitos are Cuban immigrants who arrived in the United States in 1980 or 1981 ; the natives are persons who are neither non-citizens nor naturalized citizens. The bottom panel reports statistics calculated in the sample of non-Hispanic men aged 25-59, who live in one of the 38 metropolitan areas. The ( $\Delta$ log wage) and ( $\Delta$ unemployment rate) variables give the average change between the pooled 1978-1980 CPS surveys and the pooled 1982-1985 surveys. The 1981 survey, which reports earnings for the 1980 calendar year, is not used in the calculations. 
Table 3. The impact of the Mariel supply shock on competing workers

A. First stage

Lagged supply shock

Change in native population

B. Change in log weekly wage

Mariel supply shock

Change in native population

C. Change in unemployment rate Mariel supply shock

Change in native population

D. Change in employment rate

Mariel supply shock

Change in native population

\begin{tabular}{lllll}
\multicolumn{2}{c}{ OLS } & \multicolumn{2}{c}{ IV } \\
\hline$(1)$ & & $(2)$ & $(3)$ & $(4)$ \\
\hline
\end{tabular}

$\begin{array}{ll}1.260 & 1.262 \\ (0.053) & (0.053) \\ -- & -0.002 \\ & (0.001)\end{array}$

$-1.313$

$-1.350$

$-1.264$

$-1.310$

(0.338)

$(0.346)$

$(0.320)$

$(0.322)$

0.039

---

0.039

(0.045)

(0.038)

$\begin{array}{clll}0.060 & 0.066 & 0.007 & 0.015 \\ (0.072) & (0.075) & (0.079) & (0.083) \\ -- & -0.007 & -- & -0.006 \\ & (0.019) & & (0.016)\end{array}$

$-0.001$

$-0.001$

0.052

0.053

(0.092)

(0.097)

(0.102)

(0.107)

$-0.000$

$-0.001$

(0.025)

Notes: Robust standard errors are reported in parentheses. The unit of observation is a city-education cell, and the data consist of 38 metropolitan areas and 4 education groups. The "Mariel supply shock" variable gives the ratio of the number of Marielitos in the cell to the number of natives in the cell as of 1985 . The "change in native population" variable gives the log difference in the number of native persons in the cell between 1980 and 1985. The first stage regression in Panel A relates the relative inflow of Marielitos in the cell as of 1985 to the share of Cubans in the cell as of 1980. All regressions have 152 observations and include both education fixed effects and metropolitan area fixed effects. 
Table 4. Own and cross effects of the Mariel supply shock

\begin{tabular}{lcccc} 
& $\begin{array}{c}\text { High school } \\
\text { dropouts }\end{array}$ & $\begin{array}{c}\text { High school } \\
\text { graduate }\end{array}$ & $\begin{array}{c}\text { Some } \\
\text { college }\end{array}$ & $\begin{array}{c}\text { College } \\
\text { graduates }\end{array}$ \\
\cline { 2 - 5 } A. Change in log weekly wage & -0.857 & 0.653 & 0.217 & 0.097 \\
& $(0.383)$ & $(0.331)$ & $(0.458)$ & $(0.442)$ \\
B. Change in unemployment rate & -0.156 & -0.136 & -0.386 & -0.170 \\
& $(0.223)$ & $(0.192)$ & $(0.197)$ & $(0.080)$ \\
C. Change in employment rate & 0.147 & 0.164 & 0.419 & 0.046 \\
& $(0.295)$ & $(0.235)$ & $(0.303)$ & $(0.136)$
\end{tabular}

Notes: Standard errors are reported in parentheses. The unit of observation is a city, and there are 38 metropolitan areas in the analysis. The table reports the coefficient of the "Mariel supply shock for low-skill workers," which gives the ratio of the number of Marielitos who are high school dropouts to the number of natives who are high school dropouts in 1985 in the particular city. The regressions also contain regressors giving the change in the size of the native population of each of the four education groups. The regressions are estimated separately for each education group using IV and have 38 observations. 


\section{Table 5. Size and skill composition of Soviet émigrés in Israel, 1995}

All persons (in 1000s)

Aged 25-59

Men aged 25-59

$\%$ of men aged 25-59 with education:

Less than primary

Primary completed

Secondary completed

University completed

$\%$ of men aged 25-59 working as:

Academic professionals

Associate professionals and technicians

Managers

Clerical workers

Agents, sales workers and service workers

Skilled agricultural workers

Skilled workers in industry and construction

Unskilled workers

$\%$ of men aged 25-59 with university education working as:

Academic professionals

Associate professionals and technicians

Managers

Clerical workers

Agents, sales workers and service workers

Skilled agricultural workers

Skilled workers in industry and construction

Unskilled workers

Sample Size: Men aged 25-59

\begin{tabular}{lcc}
\cline { 2 - 3 } Émigrés & Natives & $\begin{array}{c}\text { \% increase } \\
\text { in supply }\end{array}$ \\
\hline 476.4 & 4924.4 & 9.7 \\
223.6 & 1898.7 & 11.8 \\
101.6 & 934.4 & 10.9
\end{tabular}

$\begin{array}{rrr}4.5 & 11.7 & 4.2 \\ 6.2 & 20.7 & 3.3 \\ 46.0 & 49.6 & 10.1 \\ 43.2 & 18.0 & 26.2 \\ & & \\ 14.7 & 11.6 & 15.3 \\ 8.2 & 9.5 & 10.4 \\ 1.0 & 9.4 & 1.3 \\ 3.6 & 10.1 & 4.3 \\ 5.7 & 13.9 & 5.0 \\ 1.3 & 3.3 & 4.9 \\ 51.1 & 35.0 & 17.6 \\ 14.3 & 7.2 & 24.1 \\ & & \\ 29.9 & 50.5 & 17.1 \\ 11.6 & 10.4 & 32.2 \\ 1.6 & 18.0 & 2.6 \\ 4.8 & 8.4 & 16.4 \\ 5.3 & 6.6 & 23.3 \\ 1.0 & 1.2 & 24.0 \\ 35.6 & 3.8 & 267.9 \\ 10.2 & 1.2 & 249.3 \\ 10160 & 93443 & \end{array}$

Average in Israel, excluding skilled workers in industry and construction Less than primary

$\Delta \log$ earnings Sample size

Primary completed

0.12

12470

Secondary completed

0.13

25717

0.07

58279

University completed

0.17

24770

Skilled workers in industry and construction

Less than primary

0.00

2271

Primary completed

0.01

3123

Secondary completed

$-0.12$

2748

University completed

$-0.39$

542

Notes: The sample of Soviet émigrés consists of persons born in the former Soviet Union who did not reside in Israel in 1990. The sample of Israeli natives is Israeli natives consists of persons who were not born in the former Soviet Union. The bottom panel reports statistics calculated in the sample of Israeli native men aged 25-59. The ( $\Delta$ log earnings) variable gives the average change in annual earnings between the 1983 and 1995 censuses for the particular group. 


\section{Table 6. The impact of Soviet émigrés on competing workers in Israel}

\section{A. First stage}

Lagged supply shock

Change in native population

B. Change in log annual earnings

Émigré supply shock

Change in native population

\begin{tabular}{cccc}
\multicolumn{3}{c}{ OLS } & \multicolumn{2}{c}{ IV } \\
\hline$(1)$ & $(2)$ & $(3)$ & $(4)$ \\
2.686 & 2.659 & --- & -- \\
$(0.514)$ & $(0.552)$ & & -- \\
--- & 0.007 & -- & \\
& $(0.037)$ & & \\
& & & -0.611 \\
-0.730 & -0.740 & -0.616 & $(0.334)$ \\
$(0.266)$ & $(0.298)$ & $(0.316)$ & -0.004 \\
--- & 0.009 & --- & $(0.071)$
\end{tabular}

Notes: Robust standard errors are reported in parentheses. The unit of observation is an occupationeducation cell, and the data consist of 8 occupations and 4 education groups. The "émigré supply shock" variable gives the ratio of the number of Soviet émigrés in the cell to the total size of the cell as of 1995 . The "change in native population" variable gives the log difference in the number of native persons in the cell between 1983 and 1995. The first stage regression in Panel A relates the share of Soviet émigrés in the cell as of 1995 to the share of Soviet immigrants in the cell as of 1983. All regressions have 32 observations and include education fixed effects. 


\section{Table 7. Own and cross effects of the Soviet émigrés in Israel}

\begin{tabular}{lcccc} 
& $\begin{array}{c}\text { Less than } \\
\text { primary }\end{array}$ & $\begin{array}{c}\text { Primary } \\
\text { completed }\end{array}$ & $\begin{array}{c}\text { Secondary } \\
\text { completed }\end{array}$ & $\begin{array}{c}\text { University } \\
\text { completed }\end{array}$ \\
\cline { 2 - 5 } Change in log annual earnings & 0.350 & -0.070 & -0.083 & -0.739 \\
$(0.184)$ & $(0.117)$ & $(0.121)$ & $(0.208)$
\end{tabular}

Notes: Standard errors are reported in parentheses. The unit of observation is an occupation, and there are 8 occupations in the analysis. The table reports the coefficient of the "émigré supply shock for high-skill workers," which gives the ratio of the number of Soviet émigrés who completed a university education relative to the number of natives who also completed a university education in 1995 in the particular occupation. The regressions also contain regressors giving the change in the size of the native population for the own education group. The regressions are estimated separately for each occupation group using IV and have 8 observations. 


\section{Table 8. Sensitivity tests to skill downgrading}

Regressor:

Measure of supply shock:

Predicted inflow using native occupational distribution within an education group

Predicted inflow using native educational distribution within an occupation group

Change in native population
(1)

(2)

(3)

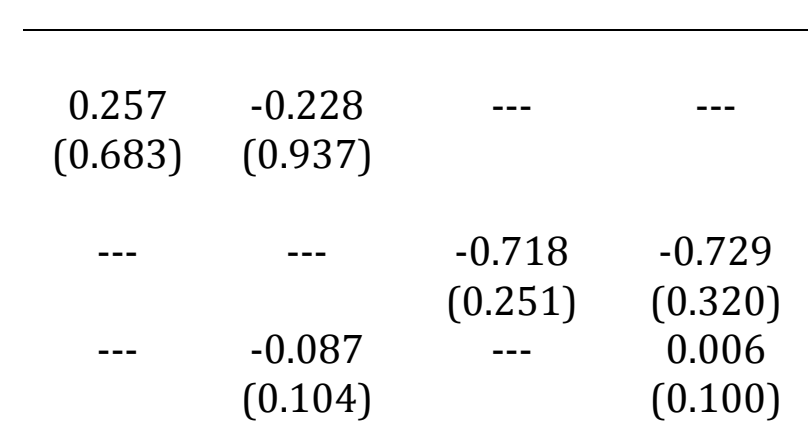

Notes: Robust standard errors are reported in parentheses. The unit of observation is an occupationeducation cell, and the data consist of 8 occupations and 4 education groups. The dependent variable is the change in log annual earnings between 1983 and 1995 for native Israelis in each cell. The regressor giving the "predicted inflow using native occupational distribution within an education group" gives the émigré supply shock calculated after assigning Soviet émigrés in each education group to occupations according to the occupational distribution of natives within each education group. The regressor giving the "predicted inflow using native educational distribution within an occupation group" gives the émigré supply shock calculated after assigning Soviet émigrés in each occupation to an educational category based on the education distribution of natives in each occupation category. All regressions have 32 observations and include education fixed effects. 


\section{Table 9. Size and skill composition of the Algerian supply shock, 1968}

All persons (in 1000s)

Aged 25-59

Male, Aged 25-59

$\%$ of men aged 25-59 with education:

Less than primary

Primary completed

Secondary completed

University completed

$\%$ of men aged 25-59 living in:

Ile de France

Lorraine

Rhone Alpes

Provence-Alpes-Cote d'Azur

$\%$ of low-skill men aged 25-59 living in:

Ile de France

Lorraine

Rhone Alpes

Provence-Alpes-Cote d'Azur

Sample size of men, aged 25-59

Average in France:

Less than primary

Primary completed

Secondary completed

University completed

Average in Provence-Alpes-Cote d'Azur:

Less than primary

Primary completed

Secondary completed

University completed

\begin{tabular}{crrcc} 
& & & \multicolumn{2}{c}{ \% increase in supply } \\
\cline { 5 - 5 } $\begin{array}{c}\text { French } \\
\text { repatriates }\end{array}$ & Algerian & French & French & Algerian \\
nationals & natives & Repatriates & nationals \\
\hline 1358.9 & 162.1 & 45732.6 & 3.0 & 0.4 \\
595.0 & 87.8 & 18610.0 & 3.2 & 0.5 \\
302.8 & 77.1 & 9079.9 & 3.3 & 0.8 \\
& & & & \\
26.1 & 96.3 & 37.2 & 2.3 & 2.2 \\
36.8 & 2.5 & 36.4 & 3.4 & 0.1 \\
25.8 & 1.0 & 20.2 & 4.3 & 0.0 \\
11.2 & 0.2 & 6.1 & 6.1 & 0.0 \\
& & & & \\
21.3 & 35.2 & 18.9 & 3.8 & 1.6 \\
3.1 & 7.3 & 4.4 & 2.3 & 1.4 \\
9.7 & 16.4 & 8.8 & 3.7 & 1.6 \\
19.2 & 15.6 & 6.3 & 10.2 & 2.1 \\
& & & & \\
17.3 & 34.6 & 13.1 & 3.1 & 5.8 \\
2.8 & 7.5 & 4.3 & 1.5 & 3.9 \\
10.6 & 16.8 & 8.2 & 3.0 & 4.5 \\
22.9 & 15.8 & 6.2 & 8.6 & 5.6 \\
15139 & 3857 & 453993 & &
\end{tabular}

$\Delta$ unemployment rate
$\Delta$ employment rate Sample size

$\begin{array}{rrr}0.01 & 0.01 & 462579 \\ 0.01 & 0.01 & 330784 \\ 0.00 & 0.00 & 159991 \\ 0.00 & 0.00 & 49703 \\ & & \\ 0.02 & -0.03 & 32188 \\ 0.01 & 0.00 & 20872 \\ 0.01 & 0.01 & 9886 \\ 0.01 & 0.01 & 3466\end{array}$

Notes: The sample of French repatriates consists of French citizens who were not living in France in 1962; the sample of Algerian nationals consists of Algerians who were not living in France in 1962; and the sample of French natives consists of French citizens who were living in France in 1962. The bottom panel reports statistics calculated in the sample of French native men aged 25-59. The ( $\Delta$ unemployment rate) and ( $\Delta$ employment rate) variables give the average change between the 1962 and 1968 censuses for the particular group. 
Table 10. The impact of French repatriates and Algerian nationals on French natives

A. First stage: share of refugees

Lagged repatriate supply shock

Lagged Algerian supply shock

\begin{tabular}{|c|c|c|c|}
\hline \multicolumn{2}{|c|}{ OLS } & \multicolumn{2}{|c|}{ IV } \\
\hline (1) & (2) & (3) & (4) \\
\hline $\begin{array}{c}1.283 \\
(0.115)\end{array}$ & $\begin{array}{c}0.067 \\
(0.053)\end{array}$ & --- & --- \\
\hline $\begin{array}{l}-0.063 \\
(0.076)\end{array}$ & $\begin{array}{c}0.558 \\
(0.027)\end{array}$ & --- & --- \\
\hline
\end{tabular}

B. Change in unemployment rate

Repatriate supply shock

Algerian supply shock

Change in native population

$$
0.063
$$

0.270

(0.067)

---
0.067

$(0.041)$

0.265

$(0.069)$

$-0.006$

(0.011)

0.089

$(0.038)$

0.247

(0.067)

$---$

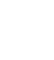

0.096

(0.039)

0.240

(0.069)

$-0.009$

(0.011)

C. Change in employment rate

Repatriate supply shock

-0.075
$(0.066)$
-0.647
$(0.206)$
---

$-0.057$

$-0.100$

$-0.083$

(0.069)

(0.077)

$-0.666$

$-0.636$

$(0.081)$

(0.211)

(0.222)

$-0.651$

$-0.022$

(0.226)

$-0.019$

(0.029)

Notes: Robust standard errors are reported in parentheses. The unit of observation is a region-education cell, and the data consist of 22 regions and 4 education groups. The "repatriate supply shock" and "Algerian supply shock" variables give the ratio of the number of French repatriates or the number of Algerian nationals in the cell to the number of French natives in the cell as of 1968. The "change in native population" variable gives the log difference in the number of native persons in the cell between 1962 and 1968. The first stage regression in Panel A relates these shares to the respective shares as of 1962. All regressions have 88 observations and include education fixed effects. 


\section{Table 11. Own and cross effects of the supply shock of Algerian nationals}

\begin{tabular}{|c|c|c|c|c|}
\hline & $\begin{array}{l}\text { Less than } \\
\text { primary }\end{array}$ & Primary & Secondary & University \\
\hline A. Change in unemployment rate & $\begin{array}{c}0.319 \\
(0.097)\end{array}$ & $\begin{array}{c}0.059 \\
(0.067)\end{array}$ & $\begin{array}{c}0.014 \\
(0.085)\end{array}$ & $\begin{array}{l}-0.039 \\
(0.093)\end{array}$ \\
\hline B. Change in employment rate & $\begin{array}{l}-0.662 \\
(0.239)\end{array}$ & $\begin{array}{l}-0.295 \\
(0.131)\end{array}$ & $\begin{array}{l}-0.349 \\
(0.139)\end{array}$ & $\begin{array}{l}-0.229 \\
(0.169)\end{array}$ \\
\hline
\end{tabular}

Notes: Standard errors are reported in parentheses. The unit of observation is a French region, and there are 22 regions in the analysis. The table reports the coefficient of the "Algerian supply shock for low-skill workers" variable, which gives the coefficient of the ratio of the number of Algerian nationals who have less than primary education to the number of natives without a primary education in 1968 in the particular city. The regressions also contain regressors giving the change in the size of the native population for each of the four education groups. The regressions are estimated separately for each education group using IV and have 22 observations. 


\section{Table 12. Size and skill composition of refugees from the former Yugoslavia, 2000}

All persons (in 1000s)

Aged 25-59

Male, Aged 25-59

Education distribution, men aged 25-59

Primary completed or less

Secondary completed

University completed

$\%$ of men aged 25-59 living in:

Austria

Greece

Ireland

Portugal

Romania

Spain

Switzerland

$\%$ of men aged 25-59 in Austria living in:

Burgenland, AUT

Niederosterreich, AUT

Wien, AUT

Karnten, AUT

Steiermark, AUT

Oberosterreich, AUT

Salzburg, AUT

Tirol

Vorarlberg, AUT

Sample size: men aged 25-59

Average in Austria

Primary completed or less

Secondary completed

University completed

Average in Vienna:

Primary completed or less

Secondary completed

University completed

\begin{tabular}{ccc} 
Refugees & European natives & \% increase in supply \\
\hline 258.6 & 94052.4 & 0.3 \\
170.2 & 49435.0 & 0.3 \\
65.1 & 24611.1 & 0.3
\end{tabular}

$\begin{array}{lll}25.1 & 44.4 & 0.1\end{array}$

$\begin{array}{lll}67.0 & 44.1 & 0.4\end{array}$

$\begin{array}{lll}7.9 & 11.5 & 0.2\end{array}$

$\begin{array}{lll}75.8 & 7.7 & 2.6\end{array}$

$\begin{array}{rrr}2.9 & 10.0 & 0.1\end{array}$

$\begin{array}{lll}0.9 & 3.6 & 0.1\end{array}$

$\begin{array}{lll}0.2 & 9.9 & 0.0\end{array}$

$\begin{array}{lll}0.9 & 20.5 & 0.0\end{array}$

$\begin{array}{lll}2.0 & 41.5 & 0.0\end{array}$

$\begin{array}{lll}17.4 & 6.8 & 0.7\end{array}$

$\begin{array}{lrr}2.3 & 3.6 & 1.7\end{array}$

$\begin{array}{lll}12.4 & 19.7 & 1.6\end{array}$

$\begin{array}{lll}33.5 & 18.9 & 4.6\end{array}$

$\begin{array}{lrr}6.8 & 6.9 & 2.6\end{array}$

$\begin{array}{lll}11.8 & 14.9 & 2.1\end{array}$

$\begin{array}{lll}16.1 & 16.9 & 2.5\end{array}$

$\begin{array}{lll}7.4 & 6.3 & 3.1\end{array}$

$\begin{array}{lll}6.3 & 8.5 & 1.9\end{array}$

$\begin{array}{lll}3.3 & 4.4 & 2.0\end{array}$

$5871 \quad 1744826$

\begin{tabular}{ccc}
$\Delta$ unemployment rate & $\Delta$ employment rate & Sample size \\
\hline 0.03 & -0.01 & 76838 \\
0.01 & -0.01 & 268539 \\
0.01 & -0.00 & 30759 \\
& & \\
0.02 & -0.01 & 17787 \\
0.03 & -0.01 & 48006 \\
0.00 & -0.00 & 10100
\end{tabular}

Notes: The sample of refugees from the Balkan Wars consists of persons born in the former Yugoslavia, but who migrated to one of the seven European countries between 1990 and 2000. The sample of European natives consists of persons not born in the former Yugoslavia. The bottom panel reports statistics calculated in the sample of European native men aged 25-59. The ( $\Delta$ unemployment rate) and ( $\Delta$ employment rate) variables give the average change between the 1990 and 2000 censuses for the particular group. 
Table 13. The impact of the Balkan supply shock on competing workers

\begin{tabular}{cccc}
\multicolumn{2}{c}{ OLS } & \multicolumn{2}{c}{ IV } \\
\hline$(1)$ & $(2)$ & $(3)$ & $(4)$ \\
0.152 & 0.144 & -- & -- \\
$(0.036)$ & $(0.036)$ & & \\
-- & 0.004 & -- & -- \\
& $(0.005)$ & &
\end{tabular}

B. Change in unemployment rate

Balkan supply shock

$\begin{array}{cc}0.209 & 0.209 \\ (0.078) & (0.103) \\ -- & -0.000 \\ & (0.016)\end{array}$

0.456

0.487

Change in native population

(0.016)

(0.311)

$(0.376)$

$---$

$-0.003$

$(0.017)$

C. Change in employment rate

Balkan supply shock

$\begin{array}{llll}-0.001 & -0.000 & -0.084 & -0.091 \\ (0.020) & (0.022) & (0.109) & (0.116) \\ -- & -0.000 & -- & 0.001 \\ & (0.002 & & (0.002\end{array}$

Change in native population

$(0.002$

Notes: Robust standard errors are reported in parentheses. The table exploits variation across 3 education groups and 65 regions located in 7 different countries. The unit of observation is a country-region-city cell. The "Balkan supply shock" variable gives the ratio of the number of Balkan refugees in the cell to the number of natives in the cell as of 2000 . The "change in native population" variable gives the log difference in the number of native persons in the cell between 1990 and 2000. The first stage regression in Panel A relates the share of Balkan refugees in the cell as of 2000 to the share of Yugoslavian migrants in the cell as of 1990. All regressions have 195 observations and include both education fixed effects and country of destination fixed effects. 


\section{Table 14. Cross effects of the Balkan supply shock}

\section{A. Change in unemployment rate}

B. Change in employment rate

\section{Primary \\ education or less}

$-1.412$

(0.951)

0.330

(0.169)

Secondary
1.056
$(0.754)$

-0.103
$(0.058)$

\section{University \\ $-0.008$ \\ $(0.411)$}

$-0.038$

$(0.051)$

Notes: Standard errors are reported in parentheses. The unit of observation is a country-region cell, and there are 65 regions located in 7 different countries.. The table reports the coefficient of the "Balkan supply shock for middle-skill workers ," which gives the ratio of the number of Balkan refugees who had completed their secondary education to the number of natives who also completed a secondary education in 2000 in the particular country-region cell. The regressions also contain regressors giving the change in the size of the native population for each of the three education groups. The regressions are estimated separately for each education group using IV and have 65 observations. 